\title{
FOREIGN EXCHANGE MARKET CONTAGION IN CENTRAL EUROPE FROM THE VIEWPOINT OF EXTREME VALUE THEORY
}

\author{
Narcisa Kadlčáková, Luboš Komárek*
}

\begin{abstract}
This paper examines contagion in the foreign exchange markets of three Central European countries and the euro area. Contagion is viewed as the occurrence of extreme events taking place in different countries simultaneously and is assessed with a measure of asymptotic tail dependence among the studied distributions. Currency crisis contagion is one strand of this research. However, the main aim of the paper is to examine the potential of bubble contagion. To this end the representative exchange rates are linked to their fundamentals using a cointegration approach. Given the long-time range required by cointegration testing, the variables are first tested for unit roots with structural breaks, whose existence is supported by these tests. In the sequel, the extreme values of the differences between actual daily exchange rates and their monthly equilibrium values determine the episodes associated with large departures from equilibrium. Using tools from Extreme Value Theory, we analyse the transmission of both standard crisis and bubble formation events in the examined currency markets. The results reveal a significant potential for contagion in the currency markets of Central Europe.
\end{abstract}

Keywords: exchange rate, extreme value theory, contagion

JEL Classification: C58, E44, G12

\section{Introduction}

Recent developments in the financial markets have shown that crises can have quick and often devastating effects in areas far beyond their epicenter. The speed, with which the recent US sub-prime crisis reached a global dimension, took economists and policy makers alike by surprise. It proved that the global nature of the current market inter-linkages makes the transmission of disequilibria across markets and regions a very likely outcome.

In this paper we look at the disequilibrium transmission within the foreign exchange markets of three Central European countries (Hungary, the Czech Republic and Poland) and the euro area. Although no major currency crises have occurred in this region, we analyse the potential co-alignment of such crises in this region. However, the main aim of the paper is to extend traditional currency crisis analysis by looking at contagion during the episodes of significant departure from exchange rate equilibrium values. This offers an insight into how likely it is that disequilibria of a bubble type are transmitted in a coordinated manner across the exchange rate markets in this area. Contagion during the disequilibrium formation process is examined using tools from cointegration and Extreme Value Theory

* Narcisa Kadlčáková, Czech National Bank, Czech Republic (narcisakad@yahoo.com); Luboš Komárek, Czech National Bank, Czech Republic (lubos.komarek@cnb.cz).

The research was supported by the Czech Science Foundation (GA CR Grants No. 16-21506S). 
(EVT). It is viewed as the occurrence of rare but extreme events taking place in different markets simultaneously, and is assessed with a measure of asymptotic tail dependence among the studied distributions. In other words, we try to answer the question: "In face of a systemic shock, are these markets going to crash together or is their response likely to differ significantly from one country to another?" In the literature, the tendency towards joint crashes in face of common adverse market movements is labelled as contagion, despite the fact that the transmission or any other causality effects and channels are not directly specified.

Currency crisis contagion is assessed in a standard way, by focussing on the extreme values of exchange rate return distributions. The prevailing understanding of currency crises is that these are the infrequent events of a high magnitude. Based on our definition of an exchange rate - number of units of domestic currency per one unit of foreign currency - depreciation events are shown in the right tails of the exchange rate return distributions. Crisis contagion is ascertained with right tail dependency measures, which are estimates of the probabilities of joint currency crisis. Although not a key result in this context, we also report the left tail (appreciation) extreme dependency measures, given that they are a by-product of our empirical estimation and might shed some light on the evolution of the exchange rates in general in the region.

Bubble formation in financial markets has been a subject of intense debating and widespread empirical research. A common and intuitive perception is to view bubbles as episodes, in which asset prices significantly depart from the optimal level suggested by their fundamentals. For instance, Komárek and Kubicová (2011) define an asset price bubble as an explosive and asymmetric deviation of the market price of an asset from its fundamental value, with the possibility of a sudden and significant reverse correction. In this paper, we follow this linkage based on fundamentals approach and describe bubble formation as extreme and infrequent departing events from fundamental equilibrium levels. It should be emphasized, however, that exchange rate bubble formation has not been acknowledged as an acute issue by officials or market participants in the considered countries.

The potential of bubble contagion is examined firstly by linking the representative exchange rates to their fundamentals using a cointegration approach. The fitted values from these cointegration relationships give the equilibrium exchange rate values at a coarser (monthly) frequency. Next, the data is considered at a daily frequency and the extreme values of the differences between actual daily asset values and their monthly equilibrium values determine the episodes associated with the large departures from equilibrium. Consequently, an EVT-based contagion approach is applied to these departures from equilibrium distributions and this forms the basis for the analysis of transmission of such bubble formation events among the analysed currency markets.

The results reveal a significant potential for contagion among the currency markets in Central Europe, both in terms of currency crises and disequilibrium formation. We look at episodes of both depreciation (right tail) and appreciation (left tail) of the examined exchange rates. In all cases our results reveal asymptotic dependence values close to one, which proves that the contagion potential in these markets is very high. 
The paper is organized as follows. Section 2 offers a brief description of the main approaches used and the related literature. Section 3 contains an overview of the main developments of the analysed exchange rates. Section 4 sheds light on the methodologies employed. The main results of the empirical analysis are presented in Section 5. The main conclusions of the paper are contained in Section 6.

\section{Literature Review}

The seminal papers of Kaminsky $(2003,2006)$, Kaminsky and Reinhart (2000) and Kaminsky et al. (1998) spurred the research related to currency crises and contagion in the aftermath of the Asian and Latin American crises of the 1990s. They searched for leading indicators that could provide a system of early warning signals for such crises. Other early attempts in dealing with contagion in currency markets were made by Eichengreen et al. (1996). More recent papers shifted the emphasis from correlation based measures, often based on ARCH-type modelling, to more sophisticated approaches assessing tail dependency measures such as Copula or EVT approaches (see Loaiza-Maya et al., 2015) and Cumperayot and Kouwenberg, 2011).

Contagion in other markets using tools from EVT has been studied by Hartmann et al. (2004). Focussing on the co-movement of extreme returns in bond and stock markets in the G5 countries, these authors found that the potential of co-crashes in stock markets and bond markets was substantial. Moreover, contagion from stock to bond markets was as frequent as flight to quality from stocks to bonds in times of crises of the former. International crisis linkages were similar to those found in the national context, a result that underscored the downside risk of financial integration. Hartmann et al. (2010) focussed on contagion in exchange rate markets in relation to the statistical properties of the exchange rate fundamentals.

Analyses of influences across countries in different segments of their financial market (the foreign exchange, stock, bond and money market) are available for Central European countries. Kočenda provides a thorough analysis of this topic in a series of seminal papers. Egert and Kočenda (2005) examine co-movements between the stock markets in Poland, the Czech Republic and Hungary on the one hand, and between the CEECs and Western European countries on the other. Evidence from intraday data reveals no robust cointegration relationship for either intra-CEEC or CEEC-Western European stock market linkages. The results suggest that it is transmission of volatility of returns, not linkages in the levels of returns, which occurs in reality. Bubák et al. (2011) found no significant spillover effects from EUR or USD into the Central European exchange rate markets; however, the volatility spillovers seemed stronger in times of market uncertainty.

Crespo-Cuaresma and Fidrmuc (2005) estimated (by means of a panel data analysis covering six Central and Eastern European countries) a monetary exchange rate model with advanced panel cointegration methods. This model (particularly when supplemented by the Balassa-Samuelson effect) could explain the long-run exchange rate relationships of a group of CEECs countries. For other markets in the CEE region, Cappiello et al. (2006) carried out an analysis of returns on equity market indices. Their results suggest that the integration of the new EU member states with the euro area increased during the process 
of the EU accession. The Czech Republic, Hungary, and Poland are found to exhibit return co-movements both between themselves and with the euro area.

The empirical analysis undertaken in this paper draws intensively from the literature dealing with unit roots testing in the presence of structural breaks, cointegration and extreme value theories.

Cointegration is a standard textbook methodology that does not require further explanation. However, the caveat that we bear in mind is that cointegration employs variables covering long-time horizons and this raises the question of the existence of structural breaks in the evolution of the employed variables. The presence of structural breaks affects the decision taken with regard to the order of integration of the variables. This is an argument originally put forward by Perron (1989) and carried on in a number of subsequent papers. The reasoning is that unit root tests have reduced power in the presence of structural breaks meaning that such tests might be biased towards the non-rejection of the unit root hypothesis even if the data were in reality stationary around a broken deterministic trend.

A stumbling block in testing for unit roots with structural breaks is the fact that these two aspects are closely interrelated. Testing for unit roots requires knowledge about the existence of a structural break and vice-versa. Unless prior knowledge about the existence of an (exogenous) break is already available deciding where to start is not obvious. A way out of this vicious circle is offered by the methodology of Perron and Yabu (2005). These two authors propose a testing procedure for the existence of a break in the trend function without prior knowledge about the stationary nature of the variables $(i . e$. I $(0)$ or I(1)). They also indicate a method of endogenously estimating the time of the break. This is done by minimizing the sum of squared residuals from regressions run at each time spot that, besides standard regressors used in the unit root setting, also include time dummies reflecting the modelled trend changes. The methodology of Perron and Yabu is applied in this paper to test for the existence of one endogenously determined structural break. As the results will show, the existence of such individual structural breaks cannot be rejected for the majority of the employed variables.

If the existence of a break is not rejected with the Perron and Yabu test, unit root tests allowing for a break in the trend function of the type proposed in Kim and Perron (2009) are further employed ${ }^{1}$. These two authors developed a unit root testing methodology assuming the existence of one break whose time of occurrence is not a-priori known. Their break identifying method coincides with the one proposed in Perron and Yabu and thus the timing of the break is the same under both approaches. If the null hypothesis of a break is rejected, the decision about the stationary nature of the series is based on standard Augmented Dickey-Fuller (ADF) and Phillips-Perron tests.

This paper also draws from the EVT part of the vast amount of economic literature related to currency and, more generally, financial crises. In the EVT approach, financial crises are viewed as rare and extreme events whose occurrence is governed by different laws

$1 \quad$ A Matlab code for the Kim and Perron test is available on these authors' web page and we used this code in our computations. 
than those governing the entire domain of studied asset return distributions. The focus is on the tails of the distributions. This allows the avoidance of some typical misassumptions, of which the most commonly made are that (a) the analysed empirical distributions follow normal distributions and (b) the Pearson correlation is a good measure of crisis dependency.

In fact, it is a common finding in the economic literature that asset returns significantly depart from the assumption of normality in the majority of markets and asset type studied. As a rule, empirical asset returns display fat tails implying that the probability of extreme events is higher than studies based on the normal distribution usually assume. Additionally, asymptotic dependence or tail-based dependence measures are usually quite different from linear dependence measures proxied by the Pearson correlation. Embrechts and al. (2002) and de Vries (2005), for instance, proved that tail dependence may still be significant among variables with a zero Pearson correlation. It is also true that asymptotic dependence is zero in the case of bivariate normal distributions with a non-zero but less than one Pearson correlation.

This paper draws inspiration from several papers employing EVT in the crisis context. Cumperayot and Kouwenberg (2011) used EVT to search for asymptotic dependence between exchange rates and several macroeconomic variables, in an attempt to find early warning signals for currency crises. From a rather comprehensive list of macroeconomic variables, asymptotic dependence was found only between domestic real interest rates and exchange rates. Their methodology was based on the approach of Poon et al. (2004) who were the first to formalize two measures of asymptotic dependence/independence for two random variables - these will be used in this paper too.

The first measure is rather intuitive. Asymptotic dependence is examined based on the conditional probability that one variable takes extreme values given that the second variable is taking such values. If the limit of such a conditional probability goes to zero when we move more deeply into the tails of the distributions, then the two variables are said to be asymptotically independent. Otherwise, if the limit is non-zero, they are considered to be asymptotically dependent.

A second measure is the measure of extreme association in the tails. It shows the speed, with which the conditional probability decays to zero. It has been proved (Ledford and Tawn, 1996) that this second measure equals one for all asymptotically dependent variables but is less than one for asymptotically independent ones. Consequently, the decision about asymptotic dependence is taken based on a test of equality to one of the second measure. If this hypothesis cannot be rejected, the two variables are said to be asymptotically dependent and the limiting conditional probability is computed. If the above hypothesis can be rejected, the two variables are said to be asymptotically independent and the conditional probability is zero at the limit.

Poon et al. 's approach was discussed and applied in a comparative manner by Schmuki (2008) who also provided a Matlab code for its practical implementation. In this paper, we employ Poon et al.'s approach and a slightly adjusted version of Schmuki's code to compute the two measures of asymptotic dependence.

We are perfectly aware of some of the limitations of implementing this approach in our study. The choice of the threshold for defining the tails was arbitrarily chosen at 
the value of $5 \%$. Coupled with a relatively short-time length of our data set, this might imply including observations that are not properly in the tail range, which could bias our results towards dependency measures characterizing the middle-range distribution. Optimal threshold selection procedures are available in the literature and we leave this issue open for future research. Another aspect worth improving is the treatment of structural breaks. Unit root tests clearly emphasize the existence of structural breaks in the behaviour of our variables. We think that they should be further considered in cointegration testing and in all the subsequent adjustments (GARCH estimations) done prior to EVT estimations. It might be that structural breaks had not significantly distorted our EVT results (at least in the CEECs case), given that their occurrences took place around the year 1999, which is the beginning of the data sample used in the EVT computations.

\section{Exchange Rate Developments and Crisis Episodes in Central Europe}

At the beginning of their transformation, Central European economies had limited capacity for absorbing large exchange rate fluctuations and that is why they initially preferred currency arrangements limiting the flexibility of the exchange rate (basket peg, adjustable peg, crawling peg). The main factors were poor development of markets, liberalization of prices and trade at the beginning of the transformation. Economic growth and liberalization of the capital account attracted foreign direct investments. Subsequently, in the second half of the 1990s, remarkable progress was made with respect to disinflation; economic development was accompanied by political and social pressure. Under such circumstances, many countries had to resist speculative attacks against their domestic currencies, which resulted in sharp movements of exchange rates (Figure 1). The most visible from among the Central European economies was the situation in the Czech Republic in May 1997. During this advanced transition phase, the Czech Republic, Poland and finally also Hungary switched to more flexible regimes (managed floating or free floating) with an inflation targeting framework (Table 1). This change in exchange rate strategy was consistent with both domestic factors (the progressive capital account liberalization in the CEEs) and external factors (the increasing risk of speculative attacks as a result mainly of Asian 1997 and Russian 1998 financial crisis). On the basis of the described changes of monetary and exchange rate regimes in CEE one can distinguish the main periods for subsequent empirical investigation.

In the Czech Republic we can distinguish three key periods. The first (1993:011996:02) was an exchange rate targeting period with conventional fixed parity of the Czech Koruna. The second (1996:02-1997:12) period was related to transitional monetary strategy toward inflation targeting. An intermediate exchange rate regime in the form of a corridor was implemented followed by the process of moving to a managed floating exchange rate regime as a result of significant exchange rate turbulences in May 1997. The third (1997:122012) period was an inflation targeting period combined with a managed floating exchange rate regime, which used FX intervention at the beginning of this period (until 2002:09) as a tool for macroeconomic stabilisation.

The Polish experience with exchange rate management leads us to distinguish also three main periods. In the first (1990:01-1995:05) Polish zloty plays the role of a nominal 
anchor. The exchange rate regime was arranged as conventional fixed parity and crawling peg with a decreasing rate of the crawl. In the second period (1995:05-2000:04), again as in the Czech Republic, a transitional monetary strategy toward inflation targeting was applied. The exchange rate regime was designed as a crawling corridor regime with widening fluctuation margins and a decreasing rate of crawl. The recent period (2000:042009:01) is characterized as a period of explicit inflation targeting and free exchange rate floating. FX intervention was not used as a tool of monetary policy.

Figure 1 | Development of Koruna, Forint and Zloty against USD and EUR

a) Czech Koruna

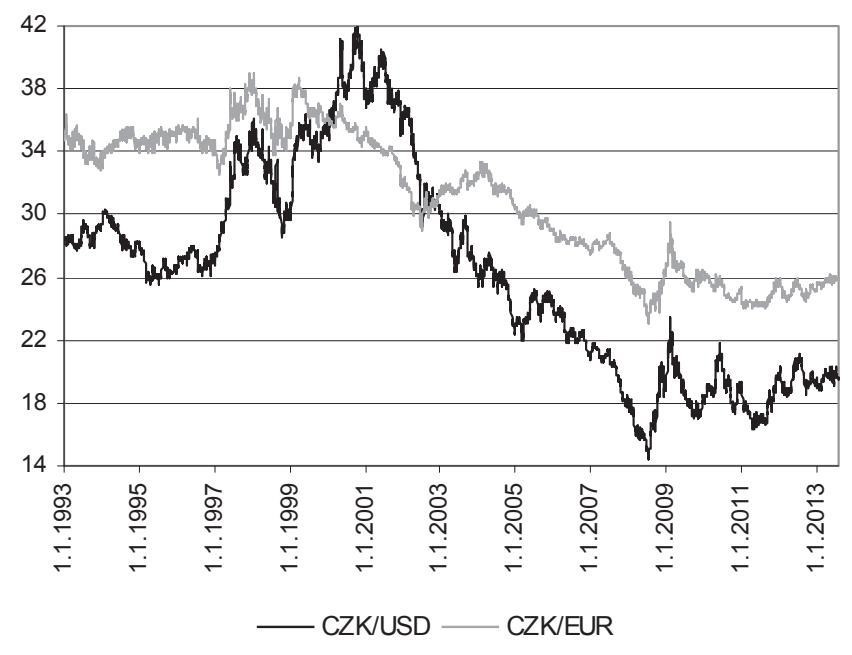

b) Hungarian Forint

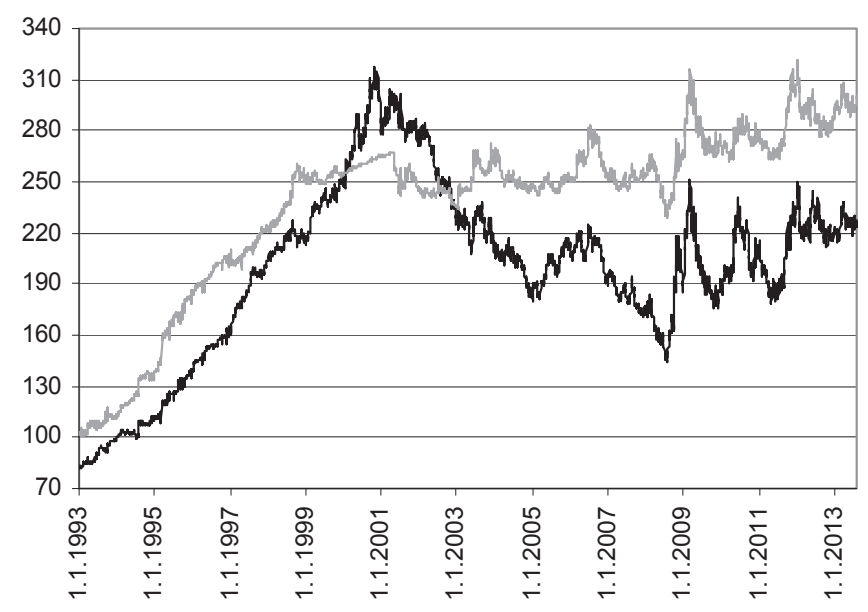

HUF/USD — HUF/EUR 


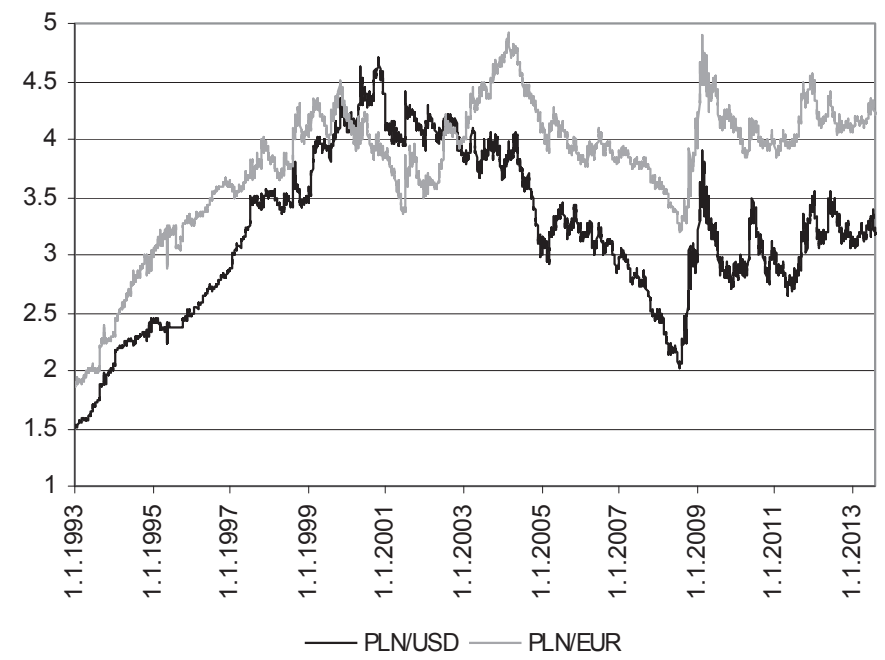

d) USD/EUR

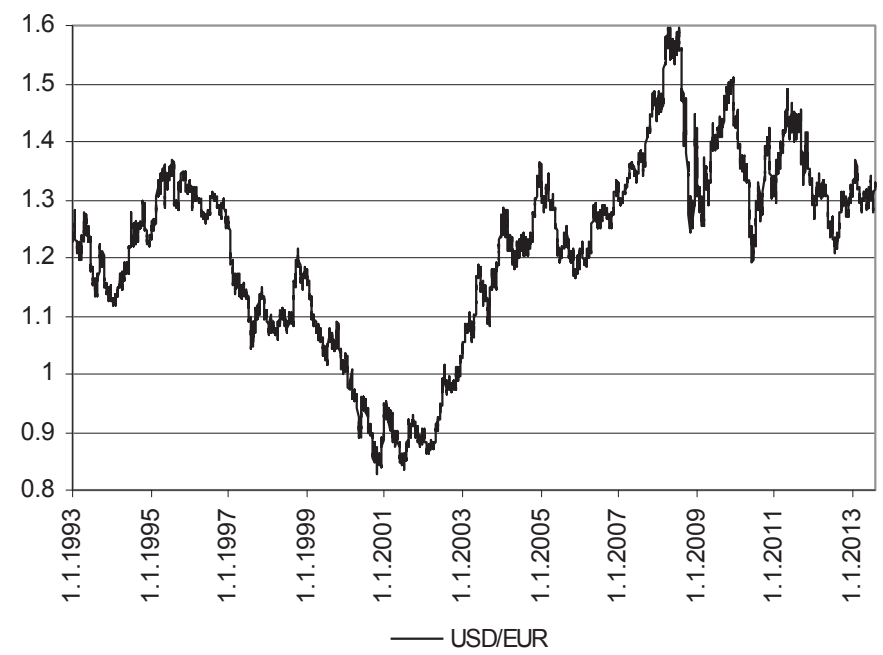

Source: Czech National Bank (CNB), Magyar Nemzeti Bank (MNB), National Bank of Poland (NBP) and Thomson DataStream. Upward movements mean depreciation of the CEE currencies and downward movements show appreciation.

The Hungarian strategy with exchange rate regimes was slightly different compared to the Czech or Polish one. It was oriented on a long-term basis to different peg arrangements, which delivered the possibility of balancing between fixed and floating exchange rates. The Hungarian case could be divided into four main stages of development. Firstly (1990:01-1995:03) they applied an adjustable peg, which also played the role of nominal 
anchor. The spring of 1995 saw a stabilization programme because Hungary was regarded by international financial institutions as the next candidate for financial crisis after Mexico in 1994. The second stage was (1995:03-2001:04) oriented to the application of a crawling peg, which was afterwards changed to a horizontal peg (2001:05-2008:02). From the end of 2008 Hungary has applied a free floating regime.

Table 1 | Exchange Rate Regimes in the Czech Republic, Hungary and Poland

\begin{tabular}{|c|}
\hline the Czech Republic \\
\hline $\begin{array}{l}\text { 03/03/1993 - 29/02/1996: Basket Peg ( } 65 \% \text { DEM, 35\% USD), Band } \pm 0.5 \% \\
\text { 01/03/1996 - 26/05/1997: Basket Peg ( } 65 \% \text { DEM, 35\% USD), Band } \pm 7.5 \% \\
\text { 27/05/1997 - present: Managed Float }\end{array}$ \\
\hline Hungary \\
\hline $\begin{array}{l}\text { 02/06/1993 - 15/05/1994: Adjustable Peg (50\% DEM, 50\% USD), Band á } \pm 0.3 ; \pm 2.25 \% \text { ñ } \\
\text { 16/05/1994 -15/03/1995: Adjustable Peg (70\% ECU, 30\% USD), Band á } \pm 0.3 ; \pm 2.25 \% n ̃ \\
\text { 16/03/1995 - 31/12/1998: Crawling Peg (70\% ECU, 30\% USD), Band } \pm 2.25 \% \\
\text { 01/01/1997 - 31/12/1998: Crawling Peg (70\% DEM, 30\% USD),, Band } \pm 2.25 \% \\
\text { 01/01/1999 - 31/12/1999: Crawling Peg (70\% DEM, 30\% USD), Band } \pm 2.25 \% \\
\text { 01/01/2000 - 30/04/2001: Crawling Peg, (100\% EUR), Band } \pm 2.25 \% \\
\text { 01/05/2001 - 25/02/2008: Horizontal Peg (100\% EUR), Band } \pm 15 \\
\text { 26/02/2008 - present: Free float }\end{array}$ \\
\hline Poland \\
\hline $\begin{array}{l}\text { 14/10/1991 - 05/03/1995: Crawling Peg (45\% USD, 35\% DEM, 10\%GBP, 5\% FRF, 5\% CHF), Band } \pm 0.6 \% \\
\text { 06/03/1995 - 15/051995: Crawling Peg ( } 45 \% \text { USD, 35\% DEM, 10\%GBP, 5\% FRF, 5\% CHF), Band } \pm 2 \% \\
\text { 16/051995 - 24/02/1998: Crawling Peg (45\% USD, 35\% DEM, 10\%GBP, 5\% FRF, 5\% CHF), Band } \pm 7 \% \\
\text { 25/02/1998 - 31/12/1998: Crawling Peg (45\% USD, 35\% DEM, 10\%GBP, 5\% FRF, 5\% CHF), Band } \pm 10 \% \\
\text { 01/01/1999 - 25/03/1999: Crawling Peg (45\% USD, 55\% EUR), Band } \pm 10 \% \\
\text { 26/03/1999 - 11/04/2000: Crawling Peg ( } 45 \% \text { USD, 55\% EUR), Band } \pm 15 \% \\
\text { 12/04/2000 - present: Free float }\end{array}$ \\
\hline
\end{tabular}

Source: Czech National Bank (CNB), Magyar Nemzeti Bank (MNB), National Bank of Poland (NBP).

A summary of in-sample extreme movements of the exchange rates is displayed in Table 2. Although longer-span data were available for the Central European countries, their extreme statistics are shown in this paper only over the period used to assess contagion, i.e. January 1999 - February 2012.

Table 2 shows the lowest/highest daily changes of the exchange rates over the period $1^{\text {st }}$ January $1999-29^{\text {th }}$ February 2012, together with the specific dates when these values occurred. For example, the maximum daily appreciation and depreciation values of the Czech koruna were $5.737 \%$ (29 ${ }^{\text {th }}$ October 2008$)$ and $4.999 \%$ ( $4^{\text {th }}$ April 2002), respectively. To get a better glimpse on how crisis events are identified in the paper, the threshold values defining the tails are also shown. For example, in the Czech case, extreme depreciation changes are those exceeding the $1.308 \%$ daily value, which is the $95 \%$ quantile of the empirical distribution of the Czech daily exchange rate changes. 
Table 2 | Extreme Values and Tail Defining Thresholds of the Exchange Rates

\begin{tabular}{|l|c|c|c|c|c|c|c|c|}
\hline \multirow{2}{*}{} & \multicolumn{4}{|c|}{ Left Tail - Appreciation } & \multicolumn{4}{c|}{ Right Tail - Depreciation } \\
\cline { 2 - 9 } & Minimum & Date & $\begin{array}{c}\text { Tail } \\
\text { Threshold }\end{array}$ & Date & Maximum & Date & $\begin{array}{c}\text { Tail } \\
\text { Threshold }\end{array}$ & Date \\
\hline CZ & $-5.737 \%$ & 29.10 .2008 & $-1.256 \%$ & 1.10 .2010 & $4.999 \%$ & 4.4 .2002 & $1.308 \%$ & 26.10 .2010 \\
\hline EU & $-4.617 \%$ & 19.3 .2009 & $-1.054 \%$ & 8.10 .2004 & $3.845 \%$ & 19.12 .2008 & $1.056 \%$ & 11.2 .2009 \\
\hline HU & $-5.520 \%$ & 29.10 .2008 & $-1.452 \%$ & 13.12 .2004 & $6.967 \%$ & 10.10 .2008 & $1.580 \%$ & 26.6 .2003 \\
\hline PL & $-21.487 \%$ & 5.1 .2009 & $-1.339 \%$ & 30.12 .2010 & $23.061 \%$ & 2.1 .2009 & $1.523 \%$ & 14.12 .2007 \\
\hline
\end{tabular}

Source: Authors' calculations based on CNB, ECB, MNB and NBP data.

We are aware that this "crisis" identifying method might considerably rely on insample information. However, perfectly objective guidelines for identifying asset crises are rarely available in empirical work. We think that our method is still superior to crisis identifying criteria of the type "plus/minus two standard deviations," which, besides the fact that they exploit the same in-sample information, may be subject to additional and often neglected limitations ${ }^{2}$. The analysis undertaken here should be viewed as an attempt to analyse coordinated extreme exchange rate movements. This could offer to policy makers in the concerned countries a first indication about the potential of synchronized exchange rate crises.

\section{Methodology}

To test for one structural change in the trend function of a variable when information about the stationary nature of the variable is not available, we apply the methodology of Perron and Yabu (2007). Their model specification is similar to Perron (1989) and allows the implementation of three types of structural change:

a change in intercept (model 1)

$$
X_{t}=a+b \cdot t+\beta \cdot D U_{t}+\alpha \cdot X_{t-1}+\sum_{i=1}^{k} \lambda_{i} \cdot \Delta X_{t-i}+\varepsilon_{t}
$$

a change in slope (model 2)

$$
X_{t}=a+b \cdot t+\gamma \cdot D T_{t}+\alpha \cdot X_{t-1}+\sum_{i=1}^{k} \lambda_{i} \cdot \Delta X_{t-i}+\varepsilon_{t},
$$

a mixed model allowing for a change in both intercept and slope (model 3)

$$
X_{t}=a+b \cdot t+\beta \cdot D U_{t}+\gamma \cdot D T_{t}+\alpha \cdot X_{t-1}+\sum_{i=1}^{k} \lambda_{i} \cdot \Delta X_{t-i}+\varepsilon_{t}
$$

2 To mention only one, is the fact that some empirical distributions with fat tails might not even allow computing their second moment. In these cases, the "plus/minus two standard deviations" rule is completely flawed. 
Here DU and DT are dummy variables controlling changes in intercept and slope, respectively:

$$
D U_{t}=\left\{\begin{array}{ll}
1 & \text { if } t>T B \\
0 & \text { otherwise }
\end{array} \quad \text { and } \quad D T_{t}= \begin{cases}t-T B & \text { if } t>T B \\
0 & \text { otherwise }\end{cases}\right.
$$

and $T B$ is the supposed time breakpoint. The augmented form of the regression is used to correct for serial correlation in error terms.

The procedure is a sequential one. It requires computing Wald statistics $\left(W_{t}\right)$ for testing the null hypothesis that the coefficients of the relevant dummy variables are zero at each considered break point candidate. The Exp-functional of Andrews and Ploberger (1994) is further constructed based on Wald statistics at all considered break points:

$$
\operatorname{Exp}_{W}=\log \left[\frac{\sum_{t} \exp \left(\frac{1}{2} W_{t}\right)}{N}\right] .
$$

The $\operatorname{Exp}_{W}$ functional has almost identical limit distributions under both assumptions of $\mathrm{I}(0)$ and $\mathrm{I}(1)$ residuals, thus providing a testing procedure with similar sizes in both cases. It also has good power properties in finite samples given the use of a bias-corrected value of the autoregressive parameter $\alpha$. The critical values of the test are determined by simulations and are based on the asymptotic distributions of the $\operatorname{Exp}_{W}$ test. The decision about the existence of a break is taken in a standard way, involving a comparison of the computed $\operatorname{Exp}_{W}$ statistic with the critical values at the chosen significance level.

In terms of EVT, a relatively standard approach is followed in this paper. At the univariate level we assess the degree of tail fatness of the distributions using the tail index. A distribution has heavy tails if it varies slowly at infinity, in other words if a positive parameter $\alpha$ exists such that:

$$
\lim _{t \rightarrow \infty} \frac{1-F(t \cdot x)}{1-F(t)}=x^{-\alpha}, x>0 .
$$

This means that in the case of a distribution with fat tail, tail probabilities decrease according to a power law, which is much slower compared with the exponential decay followed by the normal distribution.

The parameter $\alpha$ is called the tail index and is customarily estimated with the Hill estimator:

$$
\alpha=\left[\frac{1}{K} \sum_{I=1}^{K} \ln \frac{X_{N-I+1}}{X_{N-K}}\right]^{-1} .
$$

Here $K$ represents the number of observations in the tail and the values in the sum are the values above the chosen tail threshold.

The inverse of the parameter $\alpha$ ( $\gamma$, or the shape parameter) describes the shape of the tail. Positive values of $\gamma$ are characteristic for distributions with fat tails, while a $\gamma$ 
value of zero is representative for the normal distribution. For a positive $\gamma$, the number of existent moments of the distribution is determined by the tail index $\alpha$. Thus, the number of moments that can be reliably computed for a distribution with fat tails equals the greatest integer that is less or equal to $\alpha$.

Turning to multivariate EVT, a measure of asymptotic dependence can be derived starting from conditional probabilities of the type:

$$
P\left(X>F{ }_{X}^{-1}(q) Y>F{ }_{Y}^{-1}(q)\right) .
$$

This gives the probability that the random variable $X$ takes an extreme value given the occurrence of an extreme event in $Y$. Here extremeness is defined with the $q$ quantile, which is in general bounded by the $10 \%$ value on both ranges of the distribution. In our case, the 5\% and 95\% left and right ranges have been used. Asymptotic dependence in the right tail is defined with the limit of the above conditional probability when $q$ tends to one:

$$
\chi=\lim _{q \rightarrow 1} P\left(X>F-1_{X}(q) Y>F_{Y}^{-1}(q)\right) .
$$

We follow the approach of Poon et al. (2004) who describe the asymptotic dependence structure in the bivariate case with the help of the already mentioned two measures, the first of which is a limit of the type defined above and the second is a measure of the speed of convergence of the conditional probabilities to zero. If $\chi$ is non-zero, the variables are said to be asymptotic dependent and the limit $\chi$ measures the degree of such dependence. If $\chi$ is zero, the variables are asymptotic independent but the parameter $\bar{\chi}$ measures the amount of extreme association or the speed with which extreme events converge to zero for both tails.

In this paper the approach of Poon et al. is closely followed. We first apply unit Frechet transformations ${ }^{3}$ to the original data in order to eliminate the impact of the marginal distributions on the bivariate distribution function but to preserve the original dependence structure. The parameters $\chi$ and $\bar{\chi}$ are computed for the transformed series and the decision regarding asymptotic dependence/independence involves the following steps: (1) test the null hypothesis $\bar{\chi}=1$ ( $\bar{\chi}$ follows a normal distribution), (2) if this hypothesis is rejected, the series are considered to be asymptotic independent, (3) if $\bar{\chi}=1$ cannot be rejected the variables are asymptotic dependent and compute $\chi$, the final asymptotic dependence measure.

\section{Empirical Findings}

The representative assets are the exchange rates of three Central European countries (the Czech Republic, Hungary and Poland) and the euro vis-à-vis the US dollar. The quest for fundamentals is based on a money-income model (see, for example Engel and West, 2003) that is summarized by the following equation:

$$
s_{t}=\alpha_{0}+\alpha_{1} \cdot\left(m_{t}-m_{t}^{*}\right)+\alpha_{2} \cdot\left(y_{t}-y_{t}^{*}\right)+\alpha_{1} \cdot\left(p_{t}-p_{t}^{*}\right)+\alpha_{1} \cdot\left(i_{t}-i_{t}^{*}\right)+\varepsilon_{t} .
$$

3 For a more detailed explanation of the Frechet distributions and of the parameters $\chi$ and $\bar{\chi}$, see Poon et al. or Cumperayot and Kouwenberg. 
Here $s_{t}$ is the logarithm of the nominal exchange rate versus the dollar, $\mathrm{m}_{\mathrm{t}}$ is a measure of money supply (M1), $\mathrm{y}_{\mathrm{t}}$ is a proxy for output (industrial production, IP), $\mathrm{p}_{\mathrm{t}}$ is the Consumer Price Index (CPI) and $i_{t}$ is the money market interest rate (IR). Excepting the interest rates, which enter the regression as differences from the US interest rate values, all other variables are expressed in logarithmic form and are measured relative to the corresponding US variables. Cointegration relations of the type described in (10) were estimated at each country/euro area level, with the variables denoted by a star representing the US variables and those without a star being the relevant variables for the chosen country or euro area.

Dividing the variables by the corresponding US values offers a convenient way to isolate global external shocks affecting the variables in an identical manner. Equation (10) can be viewed as a combination of different simple exchange rate determination models, i.e. purchasing power parity, interest parity conditions, and the asset view of the exchange rates, viewing exchange rates as determined by the ratio of two monetary stocks.

The data were collected primarily from the International Financial Statistics (IFS) database of the IMF. However, a few variables were not available there and in those cases alternative data sources were used (Thomson Datastream and the Arad database of the Czech National Bank). The maximum time span available in those databases was used for all variables. We endeavored to collect data starting from January 1990 - the earliest available time spot for Central European Countries - to February 2012 - the latest time spot available at the time when this empirical study was launched. In several cases, and particularly in the EU case, the data became available much later. Appendix 1 summarizes the data sources and time coverage of the variables used in this paper. Representative exchange rates in logarithmic form and macroeconomic variables are also graphically displayed in Appendix 2.

\subsection{Unit root tests}

Cointegration tests can be conducted only among variables with the same order of integration. Preliminary standard Dickey-Fuller and Phillips-Perron tests including a linear deterministic trend and an intercept, suggested that all nominal exchange rates (in logarithmic form) and the majority of the macro variables considered were I(1) processes. However, we further tested for the presence of structural breaks in the deterministic functions of the variables. As already mentioned, this was done to account for the reduced power of unit root tests in the presence of structural breaks. The reduction in power of the unit root tests would imply a non-rejection of the unit root hypothesis even if the data were in reality stationary around a broken deterministic trend.

From the graphs in Appendix 2, the existence of structural breaks in the evolution of the variables gets strong support. In fact, the considered time span covers different phases in the transition process of these economies, from the initial rapid catching-up process towards Western economies, to their accession to the EU and the outburst and spread of the 2008 global crisis. One can also think in terms of less obvious reasons for the presence of structural breaks such as changes in exchange rate regimes, changes in monetary policy set-ups, etc. Based on these considerations, we judged it necessary to implement a rigorous search for structural breaks in the evolution of the employed variables. 
The Perron and Yabu methodology was applied in considering two types of structural change: (a) a change in the growth model described by a change in the slope of the deterministic trend (model 2) and (b) a mixed model that considers a change in both slope and intercept (model 3). Beyond accommodating one-time changes of the mentioned type, mixed models additionally offer a good approximation for trend changes that are not one-time events but take place gradually in time.

The results of all mentioned unit root and structural break tests are contained in Table 3 .

\section{Table 3 | Unit Root with Structural Breaks Tests Results}

\begin{tabular}{|c|c|c|c|c|c|c|c|c|}
\hline $\begin{array}{l}\text { Varia- } \\
\text { bles }\end{array}$ & $\begin{array}{l}\text { Phillips- } \\
\text { Perron UR } \\
\text { Test }\end{array}$ & $\begin{array}{c}\text { ADF UR } \\
\text { Test }\end{array}$ & $\begin{array}{l}\text { Perron } \\
\text { Yabu test } \\
\text { (Model 2) }\end{array}$ & Break Date & $\begin{array}{c}\text { Perron } \\
\text { Yabu test } \\
\text { (Model 3) }\end{array}$ & $\begin{array}{l}\text { Break } \\
\text { Date }\end{array}$ & $\begin{array}{l}\text { Kim } \\
\text { Perron } \\
\text { UR Test } \\
\text { (Model 2) }\end{array}$ & $\begin{array}{c}\text { Kim Perron } \\
\text { UR Test } \\
\text { (Model 3) }\end{array}$ \\
\hline \multicolumn{9}{|c|}{ Exchange rates (In) } \\
\hline$C Z$ & $-1.838^{\mathrm{b}}$ & $-1.926^{b}$ & $54.518^{* * *}$ & $2000 M 10$ & $54.561^{* * *}$ & $2002 M 04$ & $-3.072^{b}$ & $-3.528^{b}$ \\
\hline HU & $-1.383^{b}$ & $-1.349^{b}$ & $72.842^{* * *}$ & 2000M02 & $69.098^{* * *}$ & 2002M03 & $-3.398^{b}$ & $-3.398^{b}$ \\
\hline PL & $-1.667^{b}$ & $-1.742^{b}$ & 1.732 & No break & $3.700^{* *}$ & 1999M03 & - & $-3.553^{b}$ \\
\hline EUR & $-2.548^{\mathrm{b}}$ & $-2.574^{b}$ & -0.025 & No break & 1.249 & No break & - & - \\
\hline \multicolumn{9}{|c|}{ Fundamentals CZ } \\
\hline M1 & $-1.525^{b}$ & $-1.428^{b}$ & $53.288^{* * *}$ & 1999M12 & $52.288^{* * *}$ & 2002M03 & $-1.5646^{b}$ & $-1.6137^{b}$ \\
\hline IR & $-2.718^{b}$ & $-2.406^{b}$ & 2.116 & No break & $110.181^{* * *}$ & 1998M12 & - & $-3.614^{b}$ \\
\hline IP & $-2.334^{b}$ & $-2.380^{b}$ & 1.547 & No break & $2.954^{*}$ & $2000 \mathrm{M} 11$ & - & $-4.212^{b}$ \\
\hline CPI & $-2.800^{\mathrm{b}}$ & $-2.264^{b}$ & -0.266 & No break & $9.548^{* * *}$ & 1997M12 & - & $-3.931^{b}$ \\
\hline \multicolumn{9}{|c|}{ Fundamentals HU } \\
\hline M1 & $-0.418^{b}$ & $-0.094^{b}$ & $53.288^{* * *}$ & 1999M12 & $52.288^{* * *}$ & 2002M03 & $-3.5758^{b}$ & $-4.121^{b}$ \\
\hline IR & $-1.341^{b}$ & $-0.946^{b}$ & 0.010 & No break & $4.471^{* * *}$ & 2001M01 & - & $-3.131^{b}$ \\
\hline IP & -3.887 & -3.633 & $5.635^{* * *}$ & 1992M08 & $5.976^{* * *}$ & 1992M08 & $-2.1661^{b}$ & $-2.236^{b}$ \\
\hline CPI & $-2.855^{b}$ & $-1.921^{b}$ & 1.489 & No break & $9.923 * * *$ & 1998M06 & - & $-3.563^{b}$ \\
\hline \multicolumn{9}{|c|}{ Fundamentals PL } \\
\hline M1 & $-1.647^{b}$ & $-1.109^{b}$ & $43.803^{* * *}$ & 2008M08 & $44.0136^{* * *}$ & 2006M09 & $-2.3611^{\mathrm{b}}$ & $-2.672^{b}$ \\
\hline IR & -3.449 & -5.922 & 0.624 & No break & $12.103^{* * *}$ & 1992M10 & - & $-3.025^{b}$ \\
\hline IP & -4.948 & $-2.765^{b}$ & $8.114 * * *$ & $2001 M 10$ & $10.449 * * *$ & 2003M03 & $-3.6724^{b}$ & $-3.636^{b}$ \\
\hline CPI & -10.748 & -9.557 & $2.929 * *$ & 1996M07 & $18.566^{* * *}$ & 1996M06 & $-2.771^{b}$ & $-3.495^{b}$ \\
\hline \multicolumn{9}{|c|}{ Fundamentals EUR } \\
\hline M1 & $-0.053^{b}$ & $0.137^{b}$ & $3.654 * * *$ & 2008M02 & $3.916^{* *}$ & 2008M06 & $-3.111^{b}$ & $-3.097^{b}$ \\
\hline IR & $-1.854^{b}$ & $-2.731^{b}$ & -0.168 & No break & $8.255^{* * *}$ & 2004M09 & - & $-1.123^{b}$ \\
\hline IP & $-3.117^{b}$ & $-3.117^{b}$ & -0.085 & No break & $3.367^{* *}$ & 2008M11 & - & $-2.696^{b}$ \\
\hline CPI & -3.398 & $-1.517^{b}$ & 0.839 & No break & $6.873 * * *$ & $2005 \mathrm{M} 07$ & - & $-4.627^{b}$ \\
\hline
\end{tabular}

Notes: ${ }^{*},{ }^{* *}$ and ${ }^{* * *}$ denote a statistically significant change in trend of the mentioned type at $10 \%, 5 \%$ and $1 \%$, respectively. ${ }^{b}$ denotes non-rejection of the unit root hypothesis at $5 \%$.

Source: Authors' calculations based on CNB, ECB, MNB and NBP data. 
With the exception of the EUR/USD exchange rate variable, the hypothesis of a break cannot be rejected in any other exchange rate case. Thus, for the EUR/USD exchange rate, standard ADF and Phillips-Perron unit root tests were applied concerning its stationary nature. These tests suggested that this variable contained a unit root.

It is worth mentioning that in many cases the existence of a break could be rejected according to Model 2 but not according to Model 3. This result does not necessarily deny the existence of a break in slope. It might bring evidence that the change was rather a gradual adjustment and not a one-time change. The final decision about the existence of a structural break will in the end be taken in this paper based on the results obtained in Model 3.

In all the cases where the presence of a break was confirmed by the Perron and Yabu tests, Kim and Perron unit root tests were unable to reject the unit root hypothesis. Overall, it appears that, after controlling for the presence of a structural break, all variables are characterized by the presence of a stochastic trend. Searching for higher orders of integration, the unit root hypothesis was rejected for differenced variables in all cases excepting Polish CPI. Thus, almost all series appear to be I(1). In the Polish CPI case, the unit root hypothesis applied to the differenced series was rejected with the Phillips-Perron test but not with ADF. It is thus arguable whether this variable is I(2) or not.

\subsection{Cointegration}

Given that the majority of variables are I(1), we tested for the existence of a cointegration relationship of the type described in (10) using a standard Johansen methodology. The results are contained in Table 4 and Table 5.

In the Hungarian case both trace and rank tests supported the existence of one cointegration relationship. In the Czech, Polish and the euro area cases the presence of two cointegration relationships was supported by these tests. In the Polish case, by excluding the CPI variable one cointegration relationship was supported among the remaining variables. It might be the explosive nature of the CPI that did not allow it to be cointegrated with the remaining variables. In the Czech and the EU case one cointegration relation could be found by excluding the M1 variable. In all these three cases, the variables that contained a stochastic trend not integrated with the others were eliminated from the analysis.

The cointegration relationships were estimated with a Canonical Cointegration Regression method and are displayed in Table 4.

The Canonical Cointegration regressions represent the equilibrium relations between exchange rates and their macroeconomic fundamentals. As a final step, the equilibrium exchange rates were computed as a linear combination of the macro variables entering the cointegration relationships (or the fitted values from these regressions).

A graphical representation of the actual daily exchange rates and their monthly equilibrium levels is contained in Figure 2. This Figure also contains the histograms of the residuals between daily exchange rates and their monthly equilibrium levels. The accompanying Jarque-Bera tests show that the assumption of normality is strongly rejected in all cases. 
Table 4 | Results of the Cointegration Tests

\begin{tabular}{|c|c|c|c|c|c|c|c|c|c|}
\hline \multicolumn{10}{|c|}{ CZ (CPI, IP, IR) } \\
\hline \multicolumn{5}{|c|}{ Trace Test } & \multicolumn{5}{|c|}{ Max-Eigenvalue Test } \\
\hline $\begin{array}{l}\text { Hypothe- } \\
\text { sized No. } \\
\text { of CE(s) }\end{array}$ & $\begin{array}{l}\text { Eigen- } \\
\text { value }\end{array}$ & $\begin{array}{c}\text { Trace } \\
\text { Statistic }\end{array}$ & $\begin{array}{c}0.05 \\
\text { Critical } \\
\text { Value }\end{array}$ & Prob & $\begin{array}{l}\text { Hypothe- } \\
\text { sized No. } \\
\text { of CE(s) }\end{array}$ & $\begin{array}{l}\text { Eigen- } \\
\text { value }\end{array}$ & $\begin{array}{c}\text { Max- } \\
\text { Eigen } \\
\text { Statistic }\end{array}$ & $\begin{array}{c}0.05 \\
\text { Critical } \\
\text { Value }\end{array}$ & Prob \\
\hline None* & 0.238425 & 88.56753 & 47.85613 & 0.0000 & None* & 0.238425 & 61.28237 & 27.58434 & 0.0000 \\
\hline At most 1 & 0.084068 & 27.28516 & 29.79707 & 0.0948 & At most 1 & 0.084068 & 19.75804 & 21.13162 & 0.0769 \\
\hline At most 2 & 0.024951 & 7.527121 & 15.49471 & 0.5173 & At most 2 & 0.024951 & 5.685136 & 14.26460 & 0.6539 \\
\hline At most 3 & 0.008153 & 1.841985 & 3.841466 & 0.1747 & At most 3 & 0.008153 & 1.841985 & 3.841466 & 0.1747 \\
\hline \multicolumn{5}{|c|}{ Trace test indicates 1 cointegrating eqn(s) at the 0.05 level } & \multicolumn{5}{|c|}{$\begin{array}{l}\text { Max-eigenvalue test indicates } 1 \text { cointegrating eqn(s) at the } \\
0.05 \text { level }\end{array}$} \\
\hline \multicolumn{10}{|c|}{ EU (CPI, IP, IR) } \\
\hline \multicolumn{5}{|c|}{ Trace Test } & \multicolumn{5}{|c|}{ Max-Eigenvalue Test } \\
\hline $\begin{array}{l}\text { Hypothe- } \\
\text { sized No. } \\
\text { of CE(s) }\end{array}$ & $\begin{array}{l}\text { Eigen- } \\
\text { value }\end{array}$ & $\begin{array}{l}\text { Trace } \\
\text { Statistic }\end{array}$ & $\begin{array}{c}0.05 \\
\text { Critical } \\
\text { Value }\end{array}$ & Prob & $\begin{array}{l}\text { Hypothe- } \\
\text { sized No. } \\
\text { of CE(s) }\end{array}$ & $\begin{array}{l}\text { Eigen- } \\
\text { value }\end{array}$ & $\begin{array}{c}\text { Max- } \\
\text { Eigen } \\
\text { Statistic }\end{array}$ & $\begin{array}{c}0.05 \\
\text { Critical } \\
\text { Value }\end{array}$ & Prob \\
\hline None* & 0.212307 & 57.61533 & 47.85613 & 0.0047 & None* & 0.212307 & 36.51300 & 27.58434 & 0.0028 \\
\hline At most 1 & 0.085109 & 21.10234 & 29.79707 & 0.3513 & At most 1 & 0.085109 & 13.60937 & 21.13162 & 0.3979 \\
\hline At most 2 & 0.040054 & 7.492969 & 15.49471 & 0.5211 & At most 2 & 0.040054 & 6.254449 & 14.26460 & 0.5808 \\
\hline At most 3 & 0.008062 & 1.238520 & 3.841466 & 0.2658 & At most 3 & 0.008062 & 1.238520 & 3.841466 & 0.2658 \\
\hline \multicolumn{5}{|c|}{ Trace test indicates 1 cointegrating eqn(s) at the 0.05 level } & \multicolumn{5}{|c|}{$\begin{array}{l}\text { Max-eigenvalue test indicates } 1 \text { cointegrating eqn(s) at the } \\
0.05 \text { level }\end{array}$} \\
\hline \multicolumn{10}{|c|}{ HU (CPI, IP, IR, M1) } \\
\hline \multicolumn{5}{|c|}{ Trace Test } & \multicolumn{5}{|c|}{ Max-Eigenvalue Test } \\
\hline $\begin{array}{l}\text { Hypothe- } \\
\text { sized No. } \\
\text { of CE(s) }\end{array}$ & $\begin{array}{l}\text { Eigen- } \\
\text { value }\end{array}$ & $\begin{array}{l}\text { Trace } \\
\text { Statistic }\end{array}$ & $\begin{array}{l}0.05 \text { Criti- } \\
\text { cal Value }\end{array}$ & Prob & $\begin{array}{l}\text { Hypothe- } \\
\text { sized No. } \\
\text { of CE(s) }\end{array}$ & $\begin{array}{l}\text { Eigen- } \\
\text { value }\end{array}$ & $\begin{array}{c}\text { Max- } \\
\text { Eigen } \\
\text { Statistic }\end{array}$ & $\begin{array}{c}0.05 \\
\text { Critical } \\
\text { Value }\end{array}$ & Prob \\
\hline None * & 0.191455 & 82.55418 & 69.81889 & 0.0034 & None * & 0.191455 & 35.27811 & 33.87687 & 0.0338 \\
\hline At most 1 & 0.125928 & 47.27608 & 47.85613 & 0.0566 & At most 1 & 0.125928 & 22.34243 & 27.58434 & 0.2033 \\
\hline At most 2 & 0.089132 & 24.93365 & 29.79707 & 0.1638 & At most 2 & 0.089132 & 15.49733 & 21.13162 & 0.2556 \\
\hline At most 3 & 0.053251 & 9.436319 & 15.49471 & 0.3266 & At most 3 & 0.053251 & 9.083755 & 14.26460 & 0.2792 \\
\hline At most 4 & 0.002122 & 0.352564 & 3.841466 & 0.5527 & At most 4 & 0.002122 & 0.352564 & 3.841466 & 0.5527 \\
\hline \multicolumn{5}{|c|}{ Trace test indicates 1 cointegrating eqn(s) at the 0.05 level } & \multicolumn{5}{|c|}{$\begin{array}{l}\text { Max-eigenvalue test indicates } 1 \text { cointegrating eqn(s) at the } \\
0.05 \text { level }\end{array}$} \\
\hline \multicolumn{10}{|c|}{ PL (IP, IR, M1) } \\
\hline \multicolumn{5}{|c|}{ Trace Test } & \multicolumn{5}{|c|}{ Max-Eigenvalue Test } \\
\hline $\begin{array}{l}\text { Hypothe- } \\
\text { sized No. } \\
\text { of CE(s) }\end{array}$ & $\begin{array}{l}\text { Eigen- } \\
\text { value }\end{array}$ & $\begin{array}{l}\text { Trace } \\
\text { Statistic }\end{array}$ & $\begin{array}{l}0.05 \text { Criti- } \\
\text { cal Value }\end{array}$ & Prob & $\begin{array}{l}\text { Hypothe- } \\
\text { sized No. } \\
\text { of CE(s) }\end{array}$ & $\begin{array}{l}\text { Eigen- } \\
\text { value }\end{array}$ & $\begin{array}{c}\text { Max- } \\
\text { Eigen } \\
\text { Statistic }\end{array}$ & $\begin{array}{c}0.05 \\
\text { Critical } \\
\text { Value }\end{array}$ & Prob \\
\hline None * & 0.165006 & 51.99622 & 47.85613 & 0.0194 & None * & 0.165006 & 32.27916 & 27.58434 & 0.0115 \\
\hline At most 1 & 0.070263 & 19.71706 & 29.79707 & 0.4422 & At most 1 & 0.070263 & 13.04073 & 21.13162 & 0.4485 \\
\hline At most 2 & 0.034904 & 6.676322 & 15.49471 & 0.6156 & At most 2 & 0.034904 & 6.359389 & 14.26460 & 0.5675 \\
\hline At most 3 & 0.001769 & 0.316934 & 3.841466 & 0.5735 & At most 3 & 0.001769 & 0.316934 & 3.841466 & 0.5735 \\
\hline \multicolumn{5}{|c|}{ Trace test indicates 1 cointegrating eqn(s) at the 0.05 level } & \multicolumn{5}{|c|}{$\begin{array}{l}\text { Max-eigenvalue test indicates } 1 \text { cointegrating eqn(s) at the } \\
0.05 \text { level }\end{array}$} \\
\hline
\end{tabular}

Note: * denotes rejection of the hypothesis at the 0.05 level

All cointegration test specifications allowed for a linear deterministic trend in the data. The macro variables that were used to test for cointegration are specified in the parentheses following the country names. Source: Authors' calculations based on CNB, ECB, MNB and NBP data. 
Table 5 | Canonical Cointegration Estimations

\begin{tabular}{|c|c|c|c|c|}
\hline \multicolumn{5}{|c|}{ Canonical Cointegration Regressions } \\
\hline \multicolumn{5}{|c|}{ CZ } \\
\hline Variable & Coefficient & Std. Error & t-Statistic & Prob. \\
\hline CPI & -0.166467 & 0.167990 & -0.990934 & 0.3228 \\
\hline IP & -1.707903 & 0.110527 & -15.45232 & 0.0000 \\
\hline IR & -0.002645 & 0.004675 & -0.565704 & 0.5722 \\
\hline $\mathrm{Ct}$ & 3.201206 & 0.017421 & 183.7578 & 0.0000 \\
\hline \multicolumn{5}{|c|}{ EU } \\
\hline Variable & Coefficient & Std. Error & t-Statistic & Prob. \\
\hline CPI & 8.261419 & 0.927828 & 8.904039 & 0.0000 \\
\hline IP & 0.956911 & 0.883447 & 1.083156 & 0.2804 \\
\hline IR & -0.012222 & 0.012529 & -0.975479 & 0.3309 \\
\hline Ct & -0.182518 & 0.019739 & -9.246724 & 0.0000 \\
\hline \multicolumn{5}{|c|}{ HU } \\
\hline Variable & Coefficient & Std. Error & t-Statistic & Prob. \\
\hline CPI & -0.050247 & 0.232392 & -0.216215 & 0.8291 \\
\hline IP & 0.811780 & 0.268530 & 3.023050 & 0.0029 \\
\hline IR & -0.012904 & 0.003765 & -3.427431 & 0.0008 \\
\hline M1 & -0.664173 & 0.058006 & -11.45016 & 0.0000 \\
\hline$C t$ & 2.648403 & 0.251310 & 10.53838 & 0.0000 \\
\hline \multicolumn{5}{|c|}{ PL } \\
\hline Variable & Coefficient & Std. Error & t-Statistic & Prob. \\
\hline IP & 0.654783 & 0.131618 & 4.974878 & 0.0000 \\
\hline IR & -0.017056 & 0.002964 & -5.753988 & 0.0000 \\
\hline M1 & -0.620007 & 0.057887 & -10.71059 & 0.0000 \\
\hline$C t$ & -0.659016 & 0.177659 & -3.709454 & 0.0003 \\
\hline
\end{tabular}

Source: Authors' calculations based on CNB, ECB, MNB and NBP data. 
Figure 2 | Actual (daily frequency-black colour) and Equilibrium (monthly frequency-grey colour) Exchange Rates and Histograms of Their Differences at Daily Frequencies Frequencies against USD

The Czech Republic
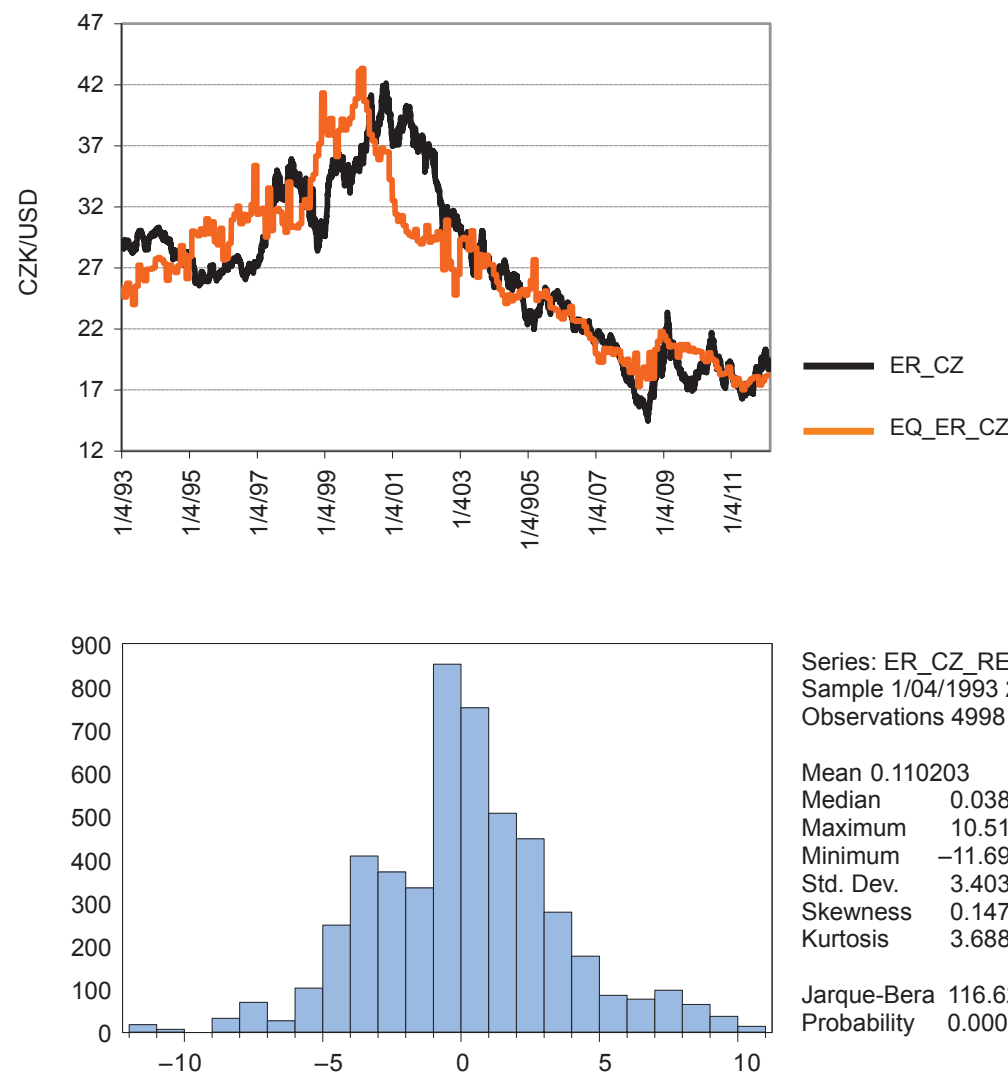

Series: ER_CZ_RESID

Sample $1 / \overline{0} 4 / 1993$ 2/29/2012

Observations 4998

Mean 0.110203

Median $\quad 0.038571$

Maximum 10.51262

Minimum $\quad-11.69273$

\begin{tabular}{lr} 
Std. Dev. $\quad 3.403282$ \\
\hline
\end{tabular}

Skewness $\quad 0.147091$

Kurtosis $\quad 3.688085$

Jarque-Bera 116.6208

Probability 0.000000

Hungary

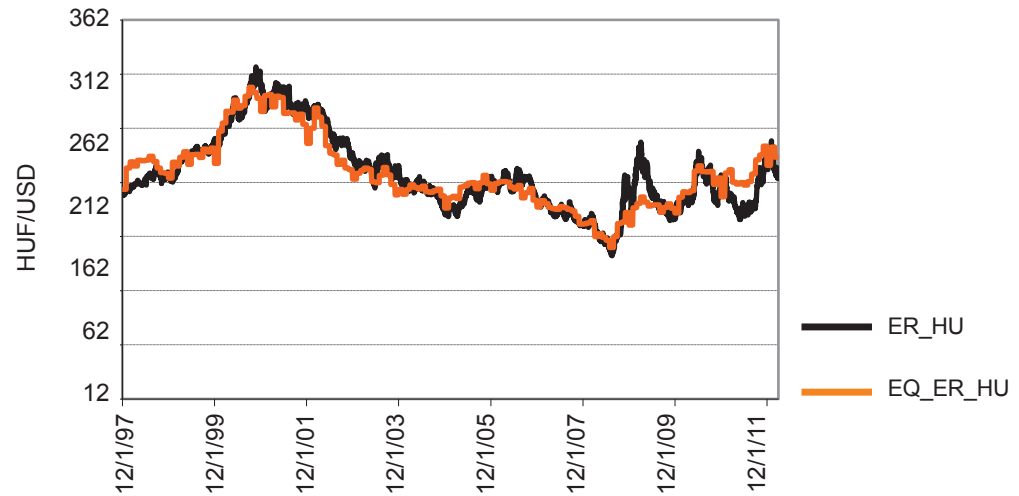


Figure 2 | continuation

Hungary

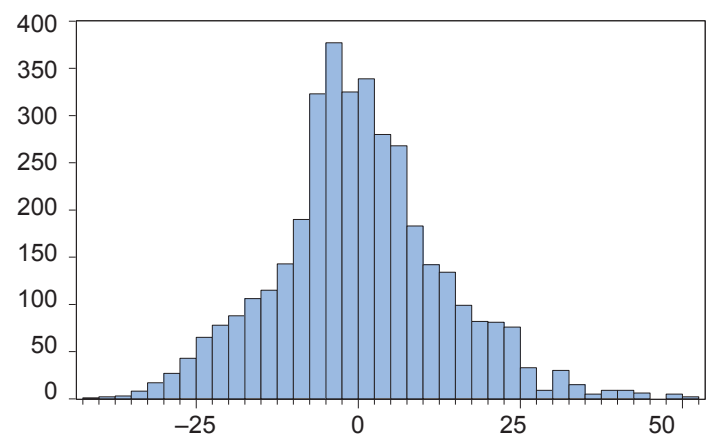

Poland
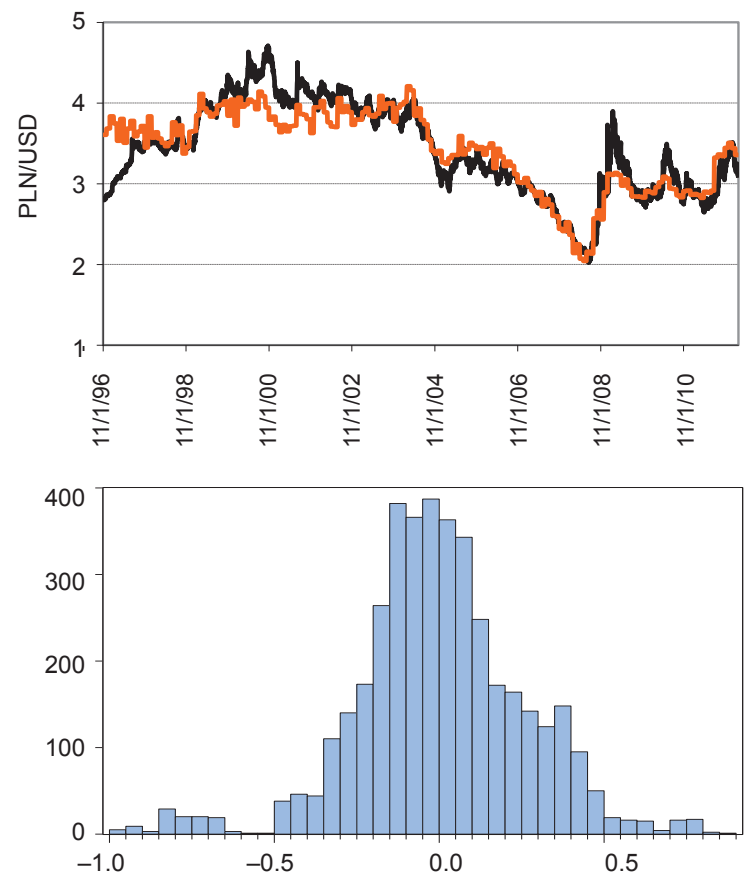

Euro area
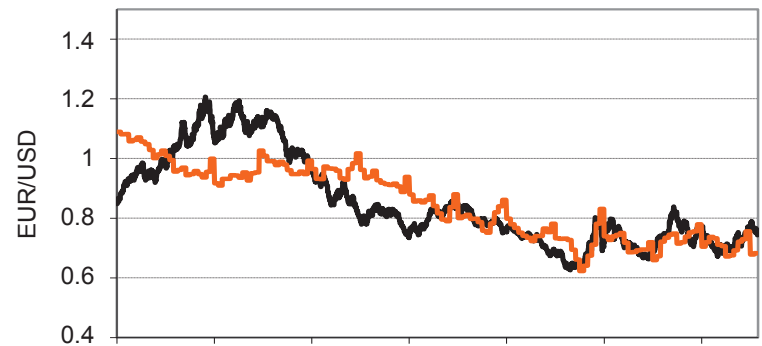

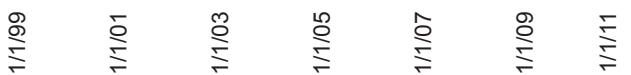

Series: ER_HU_RESID

Sample 12/01/1997 2/29/2012

Observations 3718

$\begin{array}{lr}\text { Mean } & 0.197070 \\ \text { Median } & -0.476208 \\ \text { Maximum } & 52.18027 \\ \text { Minimum } & -41.83813 \\ \text { Std. Dev. } & 13.07690 \\ \text { Skewness } & 0.275664 \\ \text { Kurtosis } & 3.634013 \\ & \\ \text { Jarque-Bera } & 109.3613 \\ \text { Probability } & 0.000000\end{array}$

Probability $\quad 0.000000$

Series: ER_PL_RESID

Sample 11/01/1996 2/29/2012

Observations 3999

$\begin{array}{lr}\text { Mean } & 0.001329 \\ \text { Median } & -0.007469 \\ \text { Maximum } & 0.892439 \\ \text { Minimum } & -0.970819 \\ \text { Std. Dev. } & 0.259609 \\ \text { Skewness } & -0.276357 \\ \text { Kurtosis } & 4.477204 \\ \text { Jarque-Bera } & 414.5002 \\ \text { Probability } & 0.000000\end{array}$




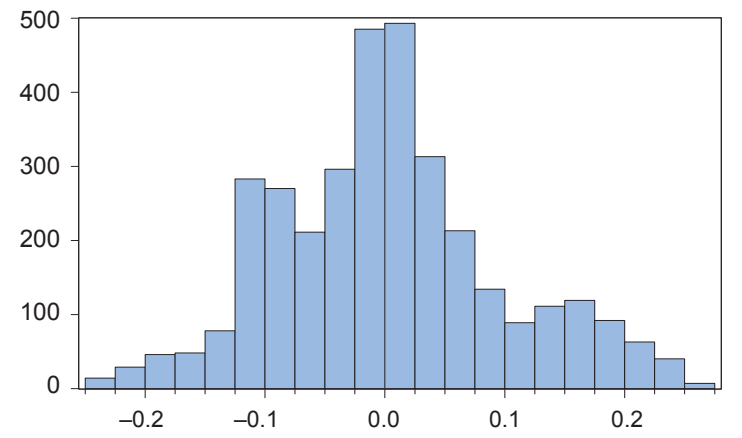

Series: ER_EU_RESID

Sample 1/01/1999 2/29/2012

Observations 3434

$\begin{array}{lr}\text { Mean } & 0.001898 \\ \text { Median } & -0.001942 \\ \text { Maximum } & 0.270006 \\ \text { Minimum } & -0.241854 \\ \text { Std. Dev. } & 0.094575 \\ \text { Skewness } & 0.323461 \\ \text { Kurtosis } & 2.985675 \\ & \\ \text { Jarque-Bera } & 59.91076 \\ \text { Probability } & 0.000000\end{array}$

Source: Authors' calculations based on CNB, ECB, MNB and NBP data.

The final time spans considered in the analysis differ among countries given the different time span availability for different variables at each country level. When implementing the EVT approach, the time span is restricted to the longest common denominator for all variables, which is $1^{\text {st }}$ January 1999-29 $9^{\text {th }}$ February 2012.

Implementing the EVT approach requires variables that are identically and independently distributed. However, correlograms of the deviation from equilibrium series obtained so far ${ }^{4}$ (at daily frequency) showed strong evidence of first-order autocorrelation, with the potential of second-order autocorrelation in the Polish case. Additionally, the variances of these series were not constant over time implying that the assumption of homoskedasticity was also violated. For these reasons, we filtered out the autocorrelation and heteroskedacity from the deviation series by estimating GARCH regressions, in which the mean equation contained lagged terms of required orders and the volatility was modelled through GARCH specifications of adequate orders. In order to account for error term distributions with heavy tails, the assumed error distribution in these regressions was a Student $t$ distribution. In the case of the exchange rate return series only the homoskedasticity assumption was not met. Thus, in this case the GARCH modelling considered only a constant in the mean equation.

For the deviation from equilibrium series, the residuals from these GARCH specifications and their histograms are contained in Figure 3.

It is clear that extreme values are present, a fact also reflected by the heavy tails of the empirical distributions. In fact, in all cases the kurtosis largely exceeds the value of 3 characteristics for normal distribution (it takes values between 22 and 38) and the skewness also suggests deviations from the normal distribution ${ }^{5}$.

Similar graphs are presented for exchange rate return series in Figure 4.

$4 \quad$ These residuals should not be confounded with the residuals from the cointegration tests, which should satisfy the i.i.d. condition given the inclusion of lagged terms in these tests' specifications.

5 In fact, the tail indices of these distributions are less than 3 suggesting that the third and fourth-order moments cannot even be reliably computed in these cases. 
Figure 3 | Deviations from the Equilibrium Series after the GARCH Filtration

EVT_RESID_CZ
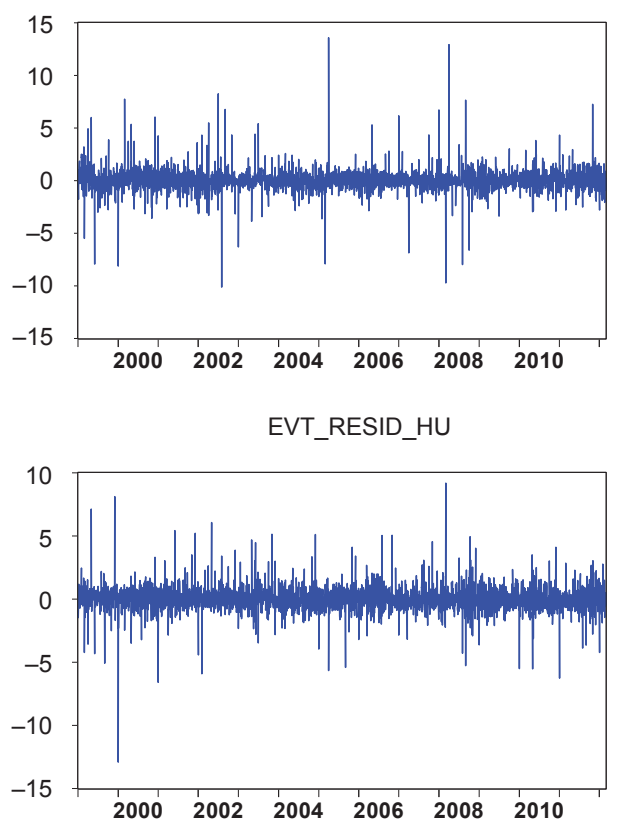

EVT_REZID_CZ

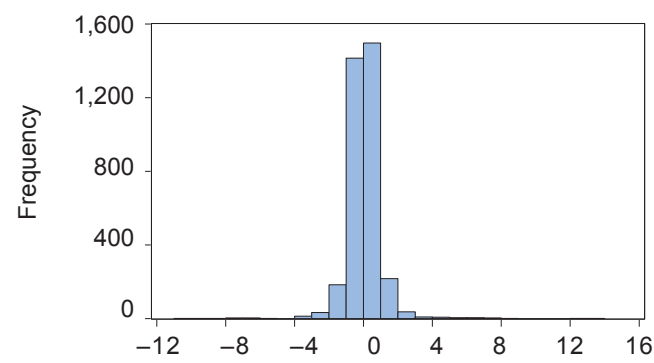

EVT_REZID_HU

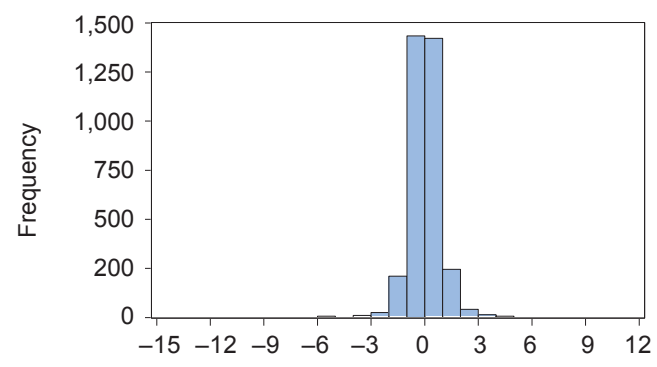

EVT_RESID_EUR
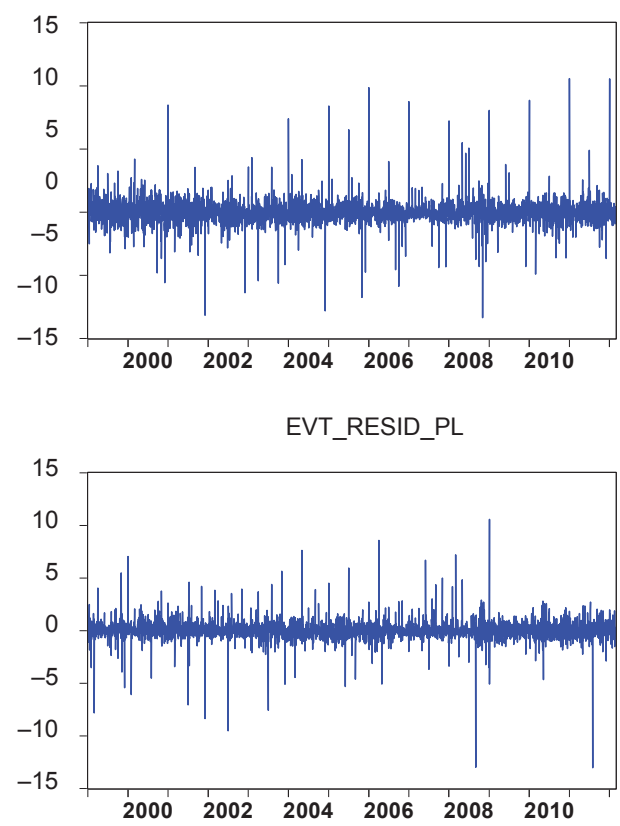

EVT_REZID_EUR

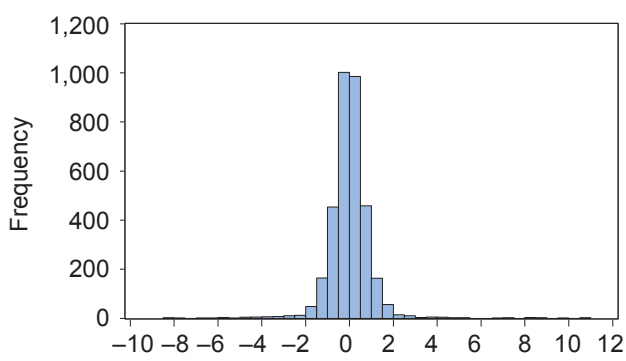

EVT_REZID_PL

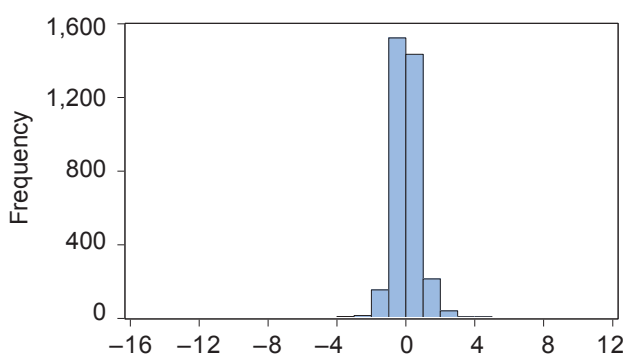

Source: Authors' calculations based on CNB, ECB, MNB and NBP data. 
Figure 4 | Exchange Rate Return Series after the GARCH Filtration

EVT_RET_CZ

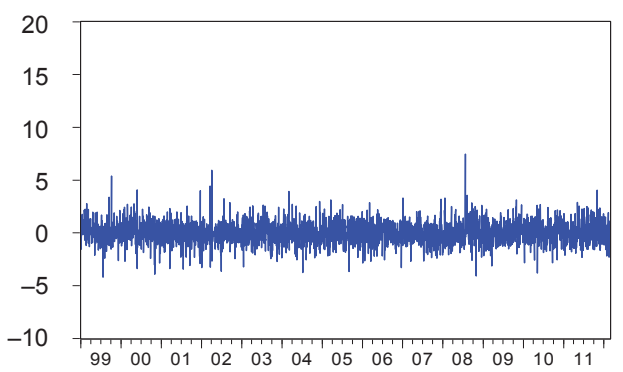

EVT_RET_HU

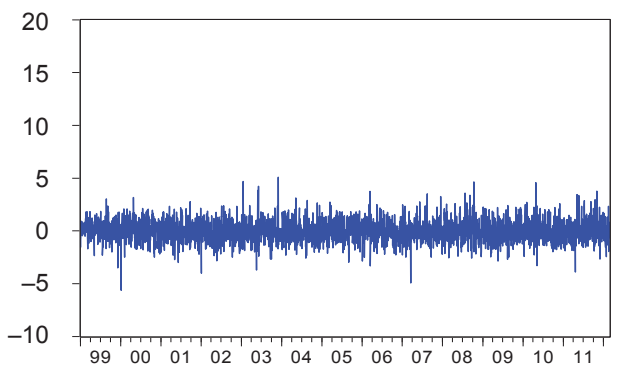

EVT_RET_CZ
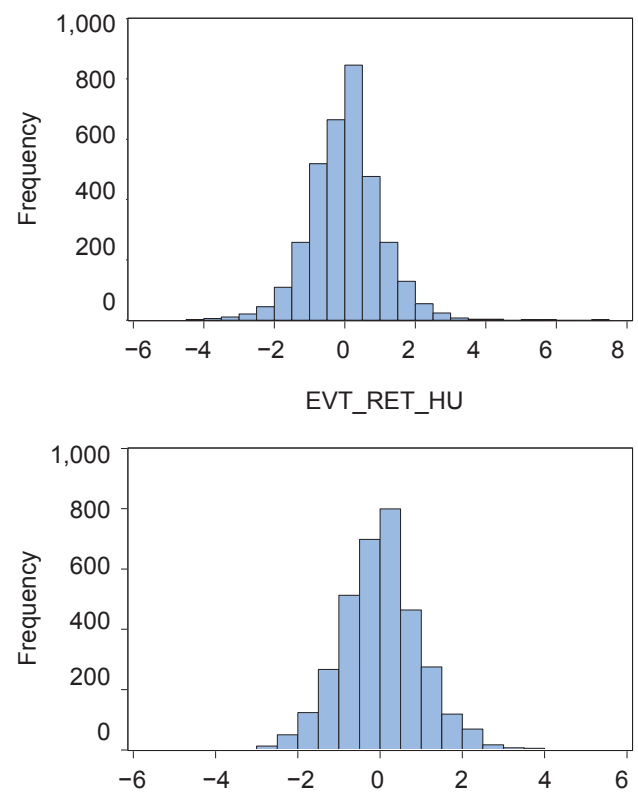

EVT_RET_EUR

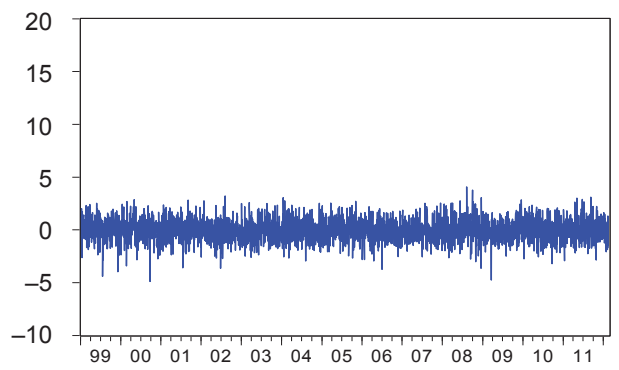

EVT_RET_PL

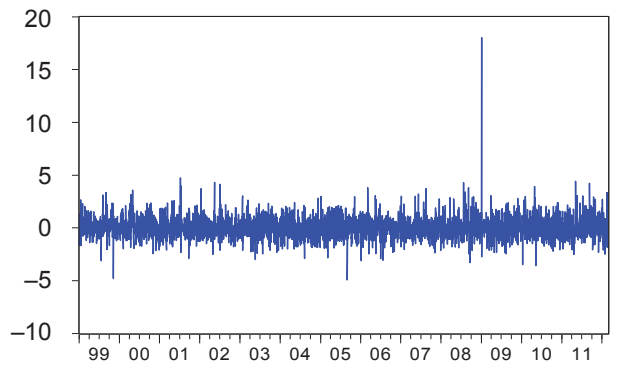

EVT_RET_EU
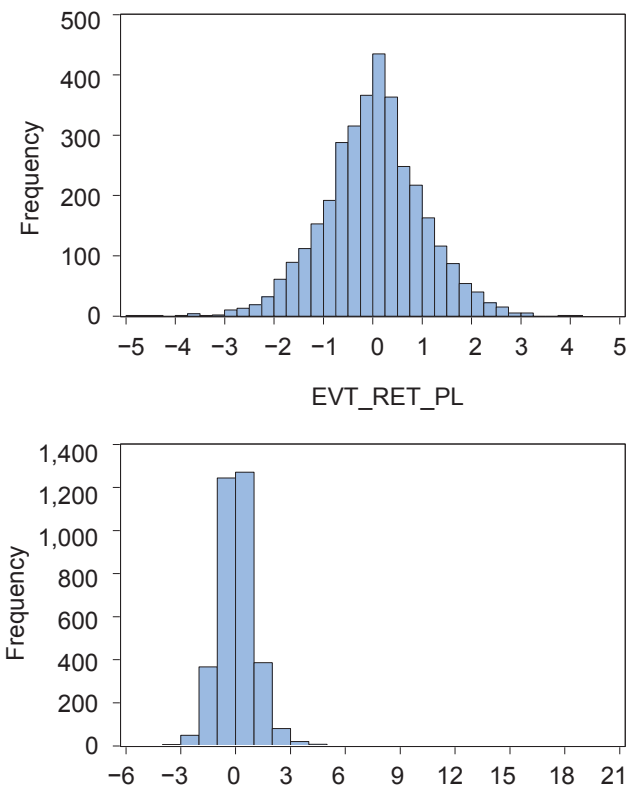

Source: Authors' calculations based on CNB, ECB, MNB and NBP data. 
Although the normality assumption is rejected in all these cases, the third and fourth order moments show values closer to those representative for the normal distribution (somehow less so in the Polish case).

\subsection{Extreme Value Theory}

The mentioned EVT tools are applied to assess the degree of asymptotic dependence among different distributions. The analysis takes into account both the left and the right tails, thus separately examining depreciation and appreciation episodes, both in terms of exchange rate returns and deviations from equilibrium.

The tail indices ( $\alpha$ parameter) at the country level are given in Table 6 .

Table 6 | Tail Indices of the Distributions

\begin{tabular}{|c|c|c|c|c|}
\hline & \multicolumn{2}{|c|}{ Deviations from equilibrium } & \multicolumn{2}{|c|}{ Exchange rate returns } \\
\hline & $\begin{array}{c}\text { Right } \\
\text { (Depreciation) }\end{array}$ & $\begin{array}{c}\text { Left } \\
\text { (Appreciation) }\end{array}$ & $\begin{array}{c}\text { Right } \\
\text { (Depreciation) }\end{array}$ & $\begin{array}{c}\text { Left } \\
\text { (Appreciation) }\end{array}$ \\
\hline CZ & 2.13 & 2.04 & 3.39 & 3.47 \\
\hline Euro area & 2.17 & 2.04 & 4.28 & 4.00 \\
\hline HU & 2.51 & 2.35 & 3.71 & 4.10 \\
\hline PL & 2.17 & 2.03 & 3.45 & 3.87 \\
\hline
\end{tabular}

Source: Authors' calculations based on CNB, ECB, MNB and NBP data.

Table 7 | Measures of Bilateral Asymptotic Dependence

Deviations from equilibrium series

\begin{tabular}{|l|c|c|c|c|c|c|}
\hline & \multicolumn{3}{|c|}{ Depreciation (right tail) } & \multicolumn{3}{c|}{ Appreciation (left tail) } \\
\cline { 2 - 7 } & $\bar{X}$ & Hypothesis $\bar{X}=1$ & $\bar{X}$ & $X$ & Hypothesis $\bar{X}=1$ & $X$ \\
\hline CZ_EUR & 0.960 & Not rejected & 0.924 & 0.924 & Not rejected & 0.946 \\
\hline CZ_HU & 0.944 & Not rejected & 0.944 & 0.906 & Not rejected & 0.945 \\
\hline CZ_PL & 1.026 & Not rejected & 0.944 & 0.875 & Not rejected & 0.936 \\
\hline HU_EUR & 0.933 & Not rejected & 0.924 & 0.968 & Not rejected & 0.945 \\
\hline PL_EUR & 1.026 & Not rejected & 0.924 & 0.922 & Not rejected & 0.936 \\
\hline HU_PL & 0.925 & Not rejected & 0.947 & 0.946 & Not rejected & 0.936 \\
\hline
\end{tabular}




\begin{tabular}{|l|c|c|c|c|c|c|}
\hline & \multicolumn{3}{|c|}{ Depreciation (right tail) } & \multicolumn{3}{c|}{ Appreciation (left tail) } \\
\cline { 2 - 7 } & $\bar{X}$ & Hypothesis $\bar{X}=1$ & $\bar{X}$ & $X$ & Hypothesis $\bar{X}=1$ & $X$ \\
\hline CZ_EUR & 0.969 & Not rejected & 0.929 & 0.962 & Not rejected & 0.940 \\
\hline CZ_HU & 0.966 & Not rejected & 0.947 & 0.950 & Not rejected & 0.940 \\
\hline CZ_PL & 0.947 & Not rejected & 0.872 & 0.950 & Not rejected & 0.940 \\
\hline HU_EUR & 0.962 & Not rejected & 0.929 & 0.986 & Not rejected & 0.950 \\
\hline PL_EUR & 0.906 & Not rejected & 0.872 & 0.978 & Not rejected & 0.947 \\
\hline HU_PL & 0.941 & Not rejected & 0.872 & 0.969 & Not rejected & 0.947 \\
\hline
\end{tabular}

Source: Authors' calculations based on CNB, ECB, MNB and NBP data.

As can be seen from Table 6 , both distributions display fat tails $(\gamma>0)$. For the exchange rate return series the existence of third-order and in some cases fourth-order moments is assured since $\alpha$ is greater than 3. However, for the deviation from equilibrium series, the maximum number of moments that can be reliably computed is two meaning that it makes sense to consider only the mean and the variance of their empirical distribution. Here extremeness is defined with the $q$ quantile, which we chose to represent $5 \%$ and $95 \%$ ranges of the distributions.

The estimated parameters $\chi$ and $\bar{\chi}$ according to the Poon at al.'s approach are shown in Table 7.

Four cases are again distinguished involving the two distributions and their left (appreciation) and right (depreciation) tails. The results suggest that significant tail dependence is present among all the pairs of exchange rate variables considered in this paper.

\section{Conclusion}

The goal of this paper was to empirically analyse the potential for contagion in three exchange rate markets in Central Europe and the euro area. Tools pertaining to Extreme Value Theory offered a suitable methodological approach and were used in conjunction with unit root tests allowing for the presence of structural breaks and cointegration.

The main finding of the paper is that the potential for contagion in the exchange rate markets of this region is particularly high. Conceived both in terms of currency crises and deviations from equilibrium, we found that all pairs of examined exchange rates exhibited high values of asymptotic dependence both on the depreciation and appreciation side.

A further insight into the behaviour of exchange rates in this region was offered by the tests of structural changes implemented in conjunction with the unit root hypothesis. It is interesting to note that with only one exception, all the variables used in this paper showed evidence for a structural break. The presence of such breaks is usually neglected 
in the empirical studies dealing with these markets and this might render their conclusions less reliable.

Another interesting result of the paper was that support for cointegration was found among all exchange rates and the small set of macro variables that we proposed as fundamentals. This result shows that these markets function in accordance with basic theoretical models, if not on a standalone basis at least as the interplay of more factors. Based on cointegration we were also able to distinguish episodes of divergence from equilibrium. It is worth noting that these were mostly predominant during the early transition period and accentuated to some extent during the recent global financial crisis. The paper also offered interesting insights into exchange rate developments in these countries from a long-term perspective.

Our results imply that financial stability policy makers should take into account the interlinkages between national financial markets. These interlinkages may manifest themselves only in the tails as during in crisis periods. Therefore, policy makers should closely monitor not only their own national financial markets but also financial markets in other relevant countries. 


\section{Appendix 1. Data Description}

\begin{tabular}{|c|c|c|c|}
\hline Variables & Source & Descriptor & Starting Date \\
\hline \multicolumn{4}{|c|}{ Czech Republic } \\
\hline ER & IFS & $\begin{array}{l}\text { National Currency per US Dollar Principal Rate, period } \\
\text { average }\end{array}$ & 1993M1 \\
\hline M1 & ARAD & Money Supply, National Currency & 1993M1 \\
\hline IR & IFS & Money Market Rate & 1993M1 \\
\hline IP & IFS & Industrial Production s.a. & 1993M1 \\
\hline CPI & IFS & Consumer Price Index & 1993M1 \\
\hline \multicolumn{4}{|c|}{ EU } \\
\hline ER & IFS & $\begin{array}{l}\text { National Currency per US Dollar, Market Rate, period } \\
\text { average }\end{array}$ & 1999M1 \\
\hline M1 & IFS & Money Supply, National Currency & 1990M1 \\
\hline IR & IFS & Interbank Rate (3-Month Maturity) & 1994M1 \\
\hline IP & IFS & Industrial Production & 1998M1 \\
\hline CPI & IFS & Consumer Prices & 1998M1 \\
\hline \multicolumn{4}{|c|}{ Hungary } \\
\hline ER & IFS & $\begin{array}{l}\text { National Currency per US Dollar, Official Rate, period } \\
\text { average }\end{array}$ & 1990M1 \\
\hline M1 & IFS & Money Supply, National Currency & 1997M12 \\
\hline IR & DATASTREAM & Hungary Interbank 3 Month - Middle Rate & 1994M1 \\
\hline IP & IFS & Industrial Production s.a. & 1990MO \\
\hline CPI & IFS & Consumer Price Index & 1990M1 \\
\hline \multicolumn{4}{|c|}{ Poland } \\
\hline ER & IFS & $\begin{array}{l}\text { National Currency per US Dollar, Commercial Rate, } \\
\text { period average }\end{array}$ & 1990M1 \\
\hline M1 & IFS & Money Supply, National Currency & 1996M12 \\
\hline IR & IFS & Money Market Rate & $1990 \mathrm{M} 12$ \\
\hline IP & IFS & Industrial Production s.a. & 1990M1 \\
\hline CPI & IFS & Consumer Prices & 1990M2 \\
\hline \multicolumn{4}{|c|}{ USA } \\
\hline ER & - & - & - \\
\hline M1 & DATASTREAM & US Money Supply M1 s.a. & 1990M1 \\
\hline IR & IFS & Federal Funds Rate & 1990M2 \\
\hline IP & IFS & Industrial Production s.a. & 1990M3 \\
\hline CPI & IFS & CPI All Items City Average & 1990M4 \\
\hline
\end{tabular}




\section{Appendix 2. Exchange Rate and Macro Variables}

\section{The Czech Republic}
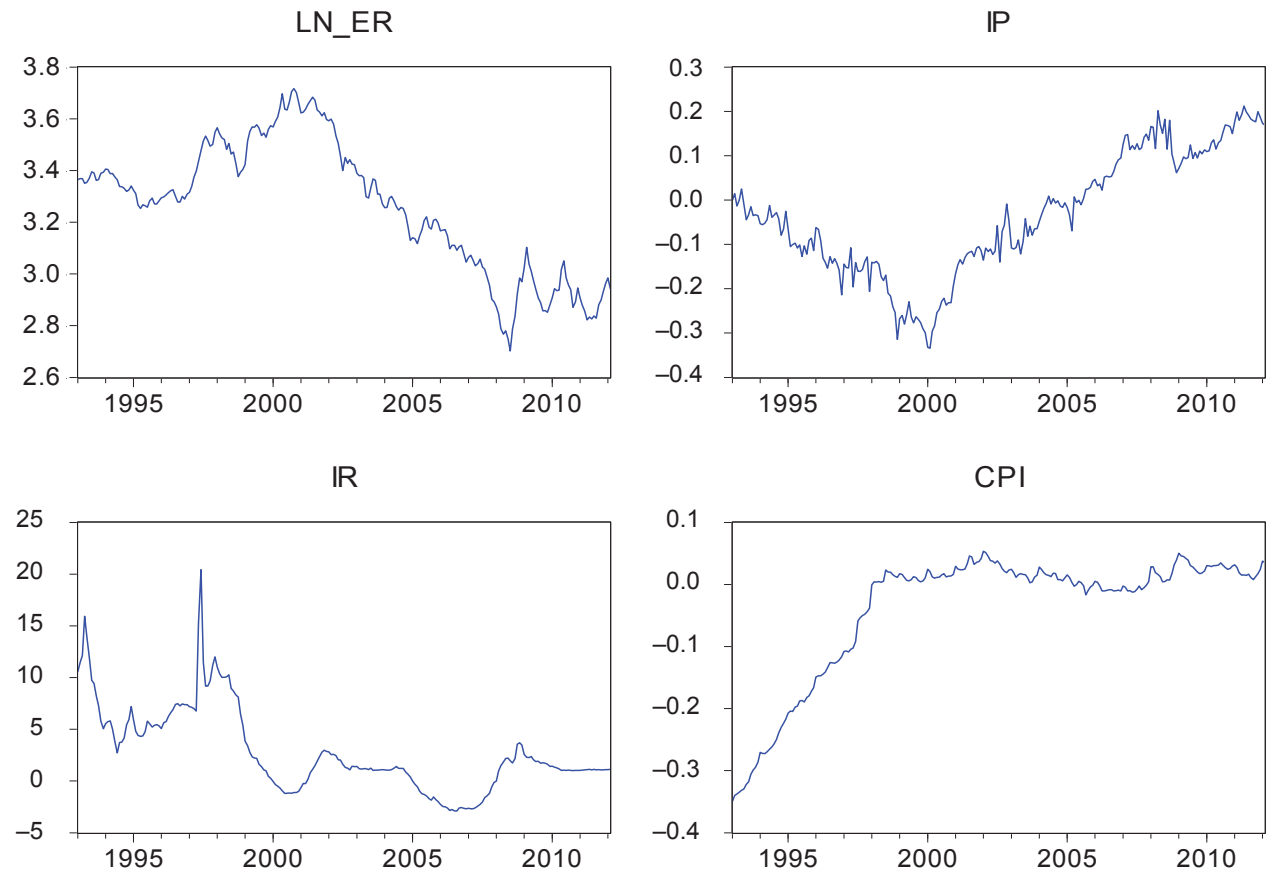

M1

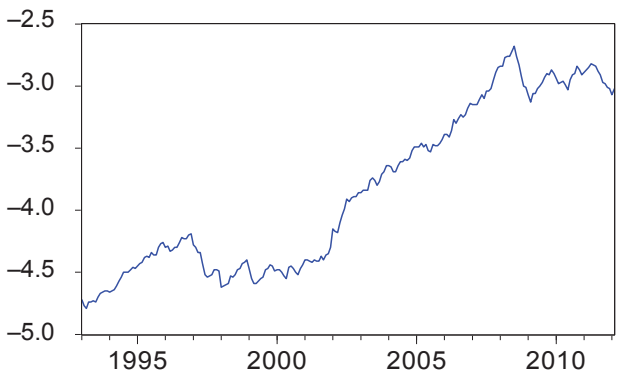


Hungary
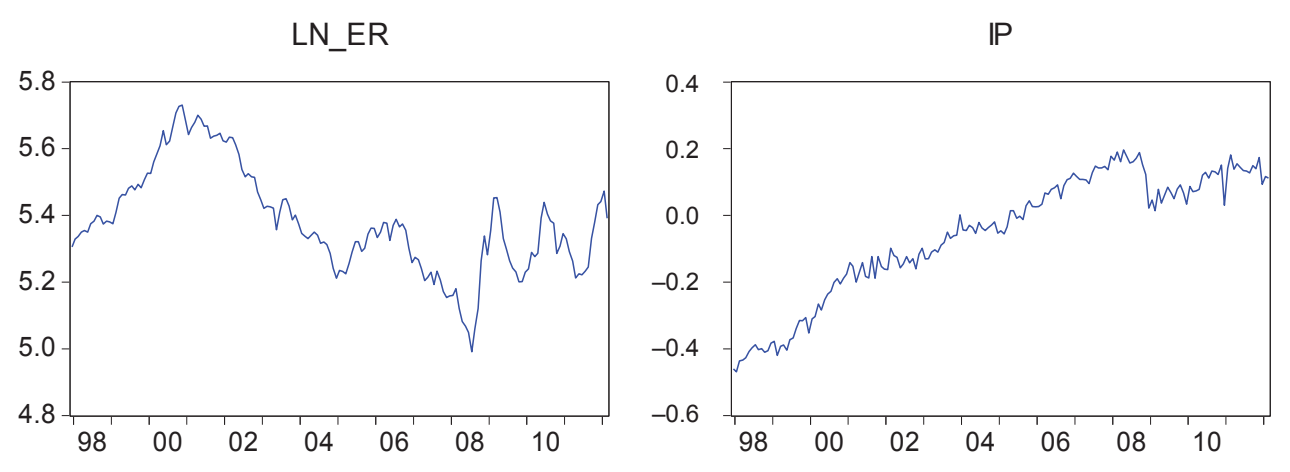

IR
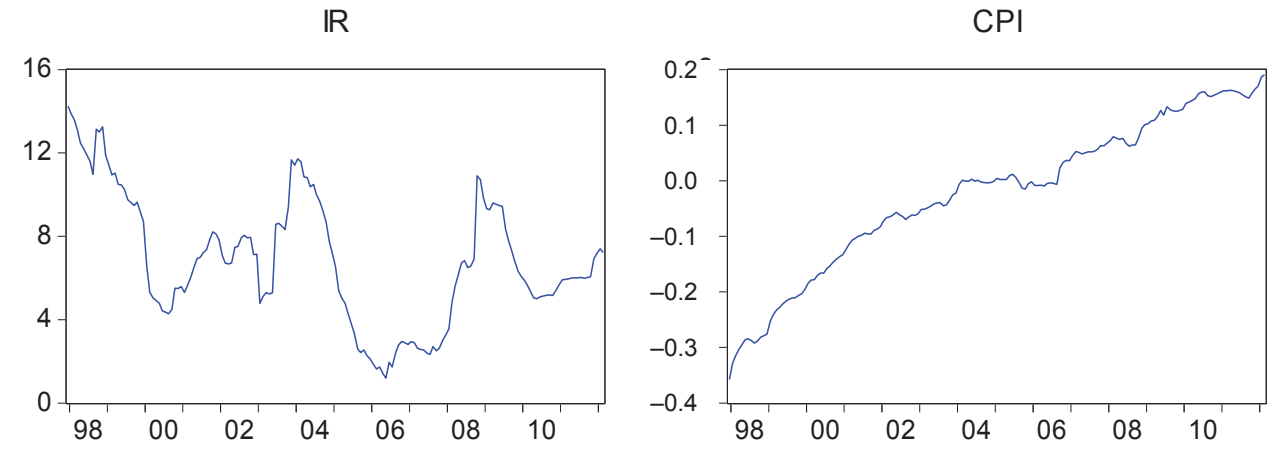

M1

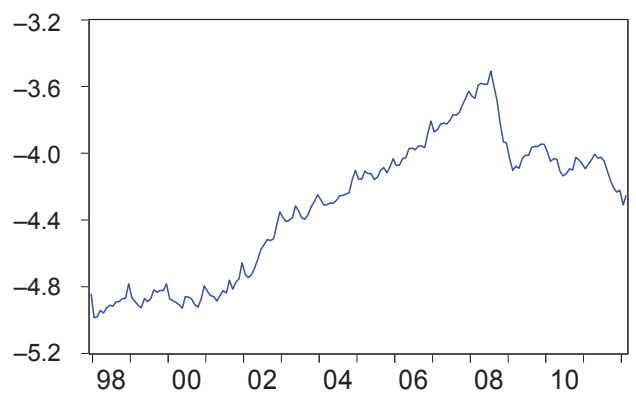




\section{Poland}
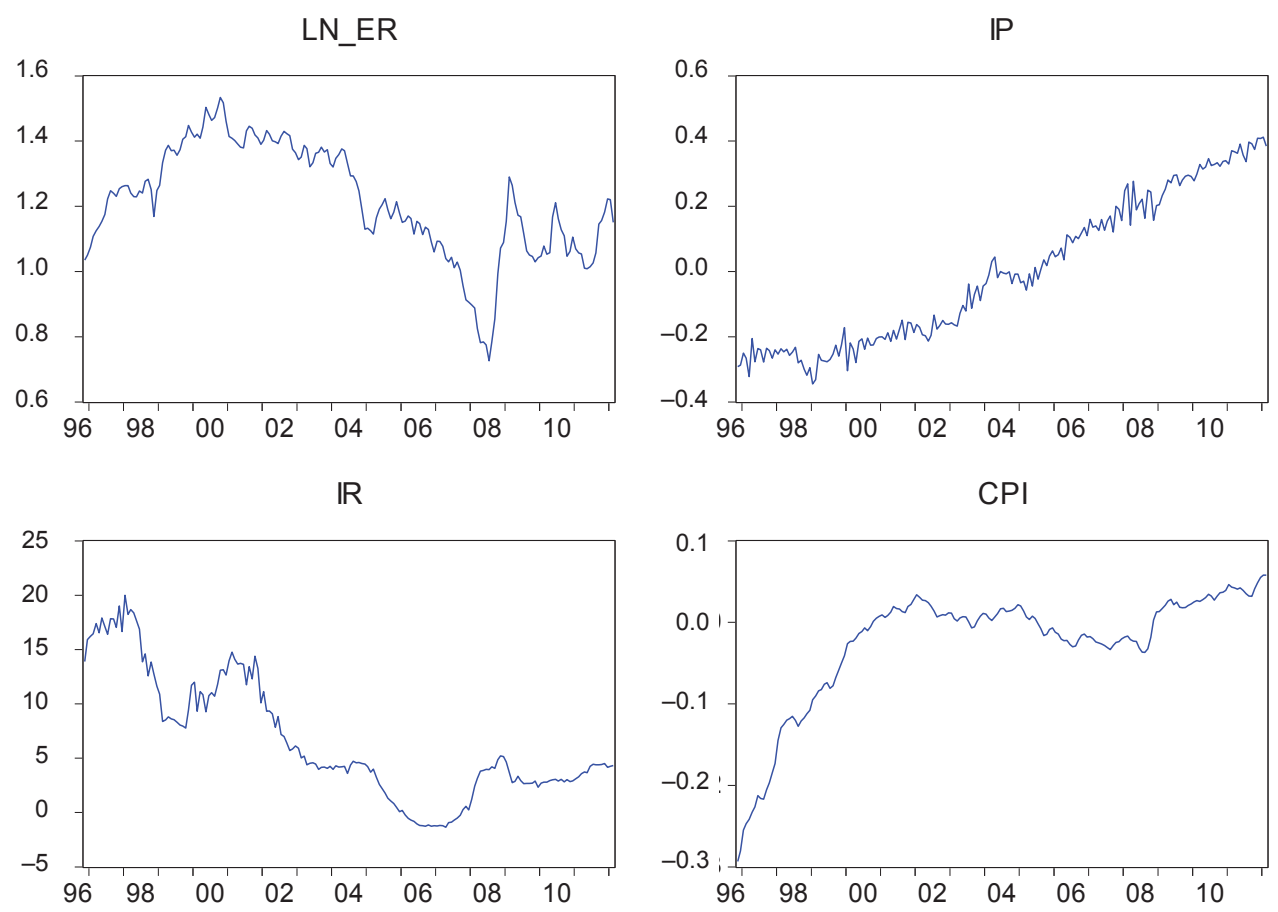

M1

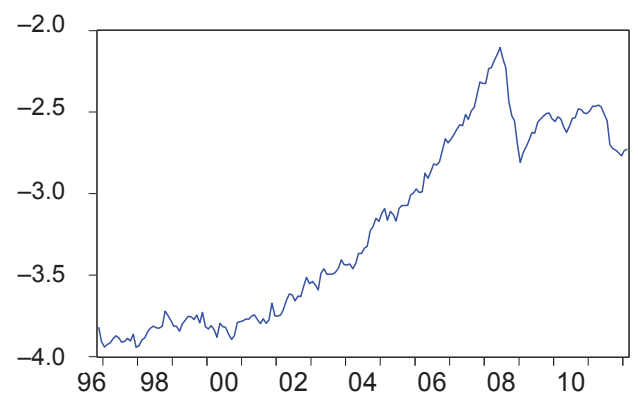




\section{Euro Area}
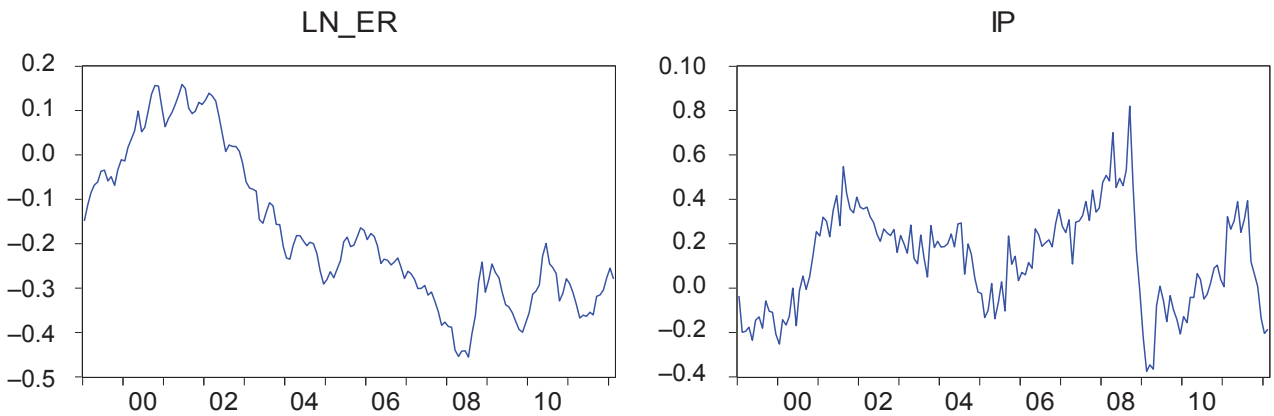

$\mathbb{R}$
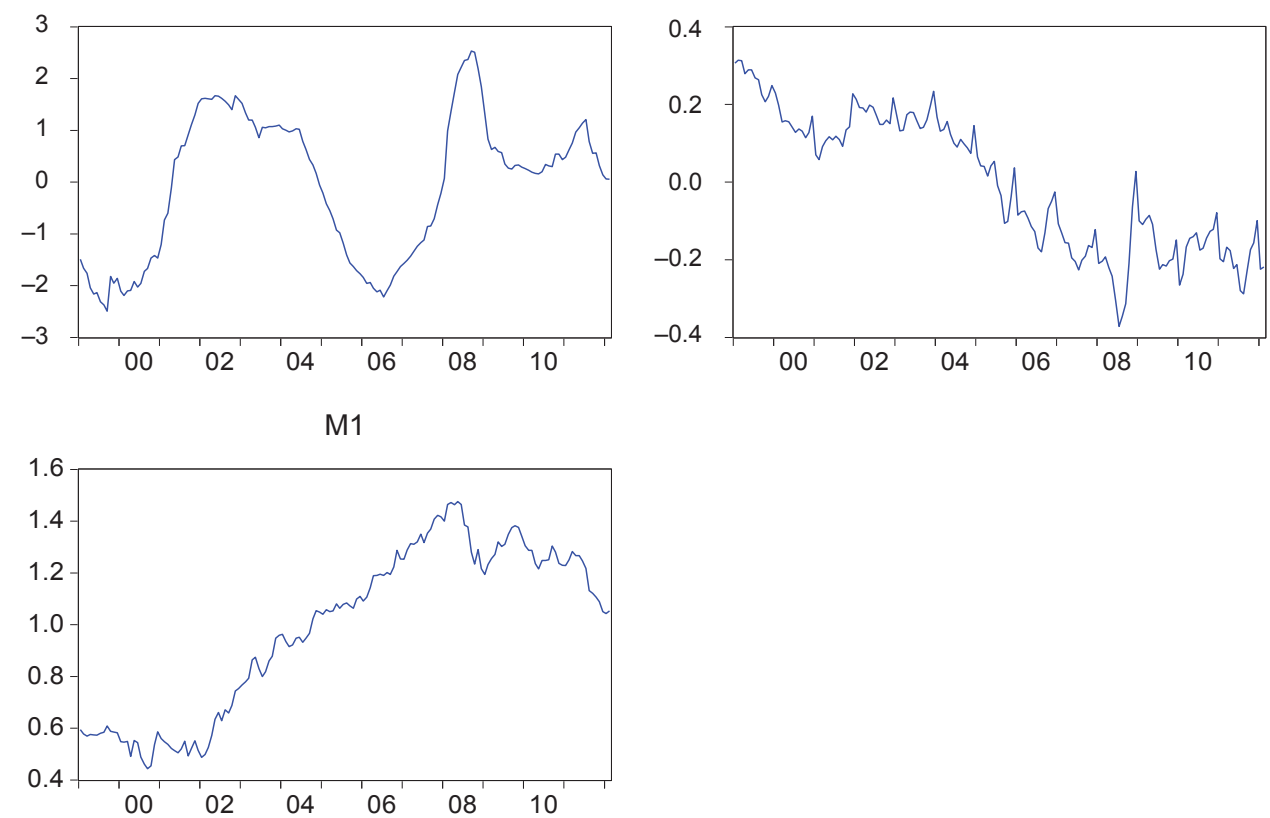

Source: Authors' calculations based on CNB, ECB, MNB and NBP data. 


\section{References}

Andrews, D. W. K., Ploberger, W. (1994). Optimal Tests When a Nuisance Parameter is Present Only under the Alternative. Econometrica, 62(6), 1383-1414, https://doi. org/10.2307/2951753

Bubák, V., Kočenda E., Žikeš, F. (2011). Volatility Transmission in Emerging European Foreign Exchange Markets. Journal of Banking and Finance, 35(11), 2829-2841, https://doi. org/10.1016/j.jbankfin.2011.03.012

Cumperayot, P., Kouwenberg, R. (2013). Early Warning Systems for Currency Crises: A Multivariate Extreme Value Approach. Journal of International Money and Finance, 36, 151-171, https://doi.org/10.1016/j.jimonfin.2013.03.008

Eichengreen, B., Rose, A. K., Wyplosz, C. (1996). Contagious Currency Crises. National Bureau of Economic Research. Cambridge Working Paper No. 5681, https://doi.org/10.3386/ w5681

Embrechts, P., McNeill, A., Straumann, D. (2002). Correlation and Dependence Properties in Risk Management: Properties and Pitfalls. Risk Management: Value at Risk and Beyond, Cambridge: Cambridge University Press, https://doi.org/10.1017/cbo9780511615337.008

Engel, C., West, K. D. (2004). Exchange Rates and Fundamentals. National Bureau of Economic Research. Cambridge Working Paper No. 10723, https://doi.org/10.3386/w10723

Hartmann, P., Straetmans, S., de Vries, C. G. (2004). Asset Market Linkages in Crisis Periods. The Review of Economics and Statistics, 86(1), 313-326, https://doi. org/10.1162/003465304323023831

Hartmann, P., Straetmans, S., de Vries, C. G. (2010). Heavy Tails and Currency Crises. Journal of Empirical Finance, 17, (2), 241-254, https://doi.org/10.1016/j.jempfin.2009.09.004

Kaminsky, G. L., Lizondo, S., Reinhart, C. M. (1998). Leading Indicators of Currency Crises. Staff Papers, 45(1).

Kaminsky, G. L., Reinhart, C. M. (2000). On Crises, Contagion and Confusion. Journal of International Economics, 15(1), 145-168, https://doi.org/10.1016/ s0022-1996(99)00040-9

Kaminsky, G. L. (2003). Varieties of Currency Crises. National Bureau of Economic Research. Cambridge Working Paper No. 10193, https://doi.org/10.3386/w10193

Kaminsky, G. L. (2006). Currency Crises: Are They All the Same? Journal of International Money and Finance, 25(3), 503-527, https://doi.org/10.1016/j.jimonfin.2006.01.002

Kim, D., Perron, P. (2009). Unit Root Tests Allowing for a Break in the Trend Function at an Unknown Time under Both the Null and Alternative Hypotheses. Journal of Econometrics, 148(1), 1-13, https://doi.org/10.1016/j.jeconom.2008.08.019

Komárek, L. Kubicová, I. (2011). The Classification and Identification of Asset Price Bubbles. Czech Journal of Economics and Finance 61(1), 34-48.

Ledford, A. W., Tawn, J. A. (1996). Statistics for Near Independence in Multivariate Extreme Values. Biometrika, 83(1), 169-187, https://doi.org/10.1093/biomet/83.1.169

Loaiza-Maya, R.A., J. E. Gomez-Gonzales, Melo-Velandia, L. F. (2015). Exchange Rate Contagion in Latin America. Research in International Business and Finance, 34, 355-367, https://doi.org/10.1016/j.ribaf.2015.02.019

Perron, P. (1989). The Great Crash, the Oil Price Shock, and the Unit Root Hypothesis. Econometrica, 57(6), 1361-1401, https://doi.org/10.2307/1913712 
Perron, P., Yabu, T. (2007). Testing for Shifts in Trend with an Integrated or Stationary Noise Component. Journal of Business and Economic Statistics, American Statistical Association, 27(3), 369-396, https://doi.org/10.1198/jbes.2009.07268

Poon, S., Rockinger, M., Tawn, J. (2003). Extreme-Value Dependence in Financial Markets: Diagnostics, Models and Financial Implications. Review of Financial Studies, 17(2), 581-610, https://doi.org/10.1093/rfs/hhg058

Schmuki, S. N. (2008). Tail Dependence: Implementation, Analysis, and Study of the Most Recent Concepts. Master Thesis, Swiss Federal Institute of Technology Zurich.

Vries, de, C. G. (2005). The Simple Economics of Bank Fragility. Journal of Banking and Finance, 29(4), 803-825, https://doi.org/10.1016/j.jbankfin.2004.08.003 